\title{
Characteristics of vegetation as determinant of Timor Friarbird (Philemon inornatus) distribution in Bipolo Lanscape of West Timor Island, Indonesia
}

\author{
BLASIUS PAGA $^{1, \bullet,}$, SATYAWAN PUDYATMOKO ${ }^{2}$, LIES RAHAYU WIJAYANTI FAIDA ${ }^{2}$, \\ IGN. PRAMANA YUDA ${ }^{3}$, NURPANA SULAKSONO ${ }^{4}$ \\ ${ }^{1}$ Department of Forestry, Politeknik Pertanian Negeri Kupang. Jl. Prof. Herman Yohanes, Lasiana, Kupang 85228, East Nusa Tenggara, Indonesia. \\ Tel.: +62-380-881600, Fax.: +62-380-881601, `email: blasiuspaga@yahoo.co.id \\ ${ }^{2}$ Faculty of of Forestry, Universitas Gadjah Mada. Jl. Agro No. 1, Bulaksumur, Sleman 55281, Yogyakarta, Indonesia \\ ${ }^{3}$ Fakultas Teknobiologi, Universitas Atma Jaya Yogyakarta. Jl. Babaksari 44, Sleman 55281, Yogyakarta, Indonesia \\ ${ }^{4}$ Balai Taman Nasional Gunung Merbabu. Jl. Merbabu No. 136, Boyolali 57316, Central Java, Indonesia
}

Manuscript received: 20 November 2020. Revision accepted: 18 April 2021.

\begin{abstract}
Paga B, Pudyatmoko S, Faida LRW, Yuda IP, Sulaksono N. 2021. Characteristics of vegetation as determinant of Timor Friarbird (Philemon inornatus) distribution in Bipolo Landscape of West Timor Island, Indonesia. Biodiversitas 22: 2617-2635. This study aims to identify vegetation factors as determinants of the distribution of Timor Friarbird (Philemon inornatus) in Timor Island. Timor Friarbird is one of the seven endemics bird species widely distributed in Timor Island, from the eastern region of Timor Leste to western region of Indonesia. This research was conducted at Bipolo Landscape, located in Timor Island, and has diversity of tropical flora diversity surrounding its Natural Tourism Park, which provides Timor Friarbird habitat. The characteristics of vegetation ecology were obtained by sampling design through Biogeography Branch's Sampling Design Tool for ArcGIS, while land use cover type was obtained by maximum likelihood method. The structure and composition of vegetation were observed through nested plot sampling, while Timor Friarbird species were assessed using the combination of point count and line transect method. The result obtained was formulated by discriminant linear regression. The vegetation parameters influencing the presence of Timor Friarbird were tree land use cover, number of trees and their species, pole land use cover, number of poles and their species, sapling land use cover, number of saplings and their species. Timor Friarbird is more likely to be present in the land cover area of poles with a minimum number of individual trees, poles, and saplings (press value $Q=6,63 \approx 7$ ). The results of discriminant analysis obtained a new group (nine variables), used collectively as a determinant factor for the presence of Timor Friarbird in their natural habitat on Timor Island.
\end{abstract}

Keywords: Determinant indicator, discriminant linear regression, Philemon inornatus, vegetation ecology

\section{INTRODUCTION}

The western area of Timor Island with a land area of $14,900 \mathrm{~km}^{2}$ is part of Indonesia, classified as a tropical area with various types of ecosystems. These include the forest forms characterized by higher plant and animal species diversity compared to other places worldwide. Monk et al. (2000) the potential for one hectare of lowland wet tropical forest can to accommodate twenty times more tree species in contrast with similar area for subtropical locations in Europe. Western Timor has a forest area of 573,317.64 ha $(32.12 \%)$ of the total land area in East Nusa Tenggara Province, at 1,784,751.04 ha (Dako et al. 2019), and the least forested area was observed in Lesser Sunda (Supriatna 2018).

The area is essential for plant and wildlife biodiversity preservation, resulting from unique ecosystems with high diversification. Dry ecosystem specificity is reflected in deciduous and rainy season forests and savanna (Lesmana et al. 2000). There are various endemic flora types, including Sandalwood (Santalum album) and Hausunaf (Ziziphus timorensis). The specified habitats in areas with significant endemic species threatened are a priority for area conservation action (Bacchetta et al. 2011). Timor Friarbird (Philemon inornatus) is one of the seven endemic birds on Timor Island. The endemic flora, fauna, and microbes indicate uniqueness in geology and ecosystem (Darajati et al. 2016), which is a component estimated to support the local ecology (Isworo \& Oetari 2020). Timor Friarbird distribution status is Restricted-range (R) and Endemic Birds Areas (EBAs) category, Timor Island and its surroundings (Wetar, Rote and Semau) are in number 164 of 218 EBAs in the world (Trainor 2002). The species' IUCN status is Least-Concern (LC) (BirdLife International, 2018).

The Timor Friarbird, also known as "koakiko" or "kolokoa" plays an important role in the life of the local residents. This species possesses the following morphological characteristics: having a body measuring 24 $\mathrm{cm}$, plain eyes and slightly bald skin around the eyes (Coates \& Bishop 2000; Eaton et al. 2016), as well as living in pairs or small groups (Eaton et al. 2016). These species play an important role in maintaining ecological balance, environmental sustainability, and further serve as bio-indicators for environmental health conditions. Studies have also shown the intrinsic dynamic flexibility, high mobility, the important role played in the food chain, and 
ecological network (Bender et al. 2017) and adaptation capability to various environments (Newbold et al. 2013).

The species serve as a time marker for the local community to start and end daily activities. Lesmana et al. (2000) reported on the ability for Timorese people to understand bird functioning as a signal indicating some natural phenomena.

Habitat diversity impacts on vegetation structure characteristics, while the vegetation composition reflects the ecology, through the number of species, individuals, height, basal area and volume. These properties are important in conservation, and both are dependent on other interacting ecosystem components (Arrijani et al. 2006). Dutta and Devi (2013) determined the habitat features by evaluating vegetation structure, species diversity and regeneration status. Detailed ecological analysis of an area potentially provides an overview of the structure and composition in a habitat. Prior research has shown the impact of threat control on forest status and quality and the opportunity to design conservation efforts in the future (Rachmat et al. 2018; Susilowati et al. 2019). The structure and composition play an important role in the survival of various wildlife species, especially for arboreals, known to predominantly depend on the existence of different growth levels. Isworo and Oetari (2020) attributed the difficulty of discovering some bird species in limited vegetation areas to disrupt feeding, breeding, and resting areas. Vegetation studies are very important due to the useful basic data provided while formulating conservation strategies and species management, especially for individuals with high vulnerability levels (Susilowati et al. 2020).

The species known to grow naturally in a certain area reflects the interaction existing between various environmental factors, and are estimated to undergo drastic changes, resulting from anthropogenic influences (Setiadi 1984; Sundarapandian and Swamy 2000). Land use modification is a major driver of loss in biodiversity, both presently and possibly in the future (Newbold et al. 2013). Despite the considerable anthropogenic activities observed in this landscape, several current points of encounter with Timor Friarbirds are possible in different habitats. Therefore, habitats with various vegetation structure and composition characteristics instigate adaptation as an important site for optimal distribution. This indicates the possibility of evaluating the presence and absence in the area. Therefore, a study on the ecological factors of the vegetation in this landscape is necessary for this determination, and is also essential to support future conservation programs. The aim of this study, is to identify several vegetation parameters, peculiar to determine the presence of Timor Friarbird in the natural tropical habitat of Timor Island.

\section{MATERIALS AND METHODS}

\section{Study area}

This study was conducted in the landscape area of 1,659 Ha, administratively located in Bipolo and Oeteta Village, Sulamu Subdistrict, Kupang District, Nusa Tenggara Timur Province, and commenced in November 2019 to January 2020. Geographically, Bipolo Landscape is located in $10^{\circ} 00^{\prime} 29,14 \mathrm{~S}$ and $123^{\circ} 48^{\prime} 03,47^{\prime}$ ' $\mathrm{E}$ (Figure 1).

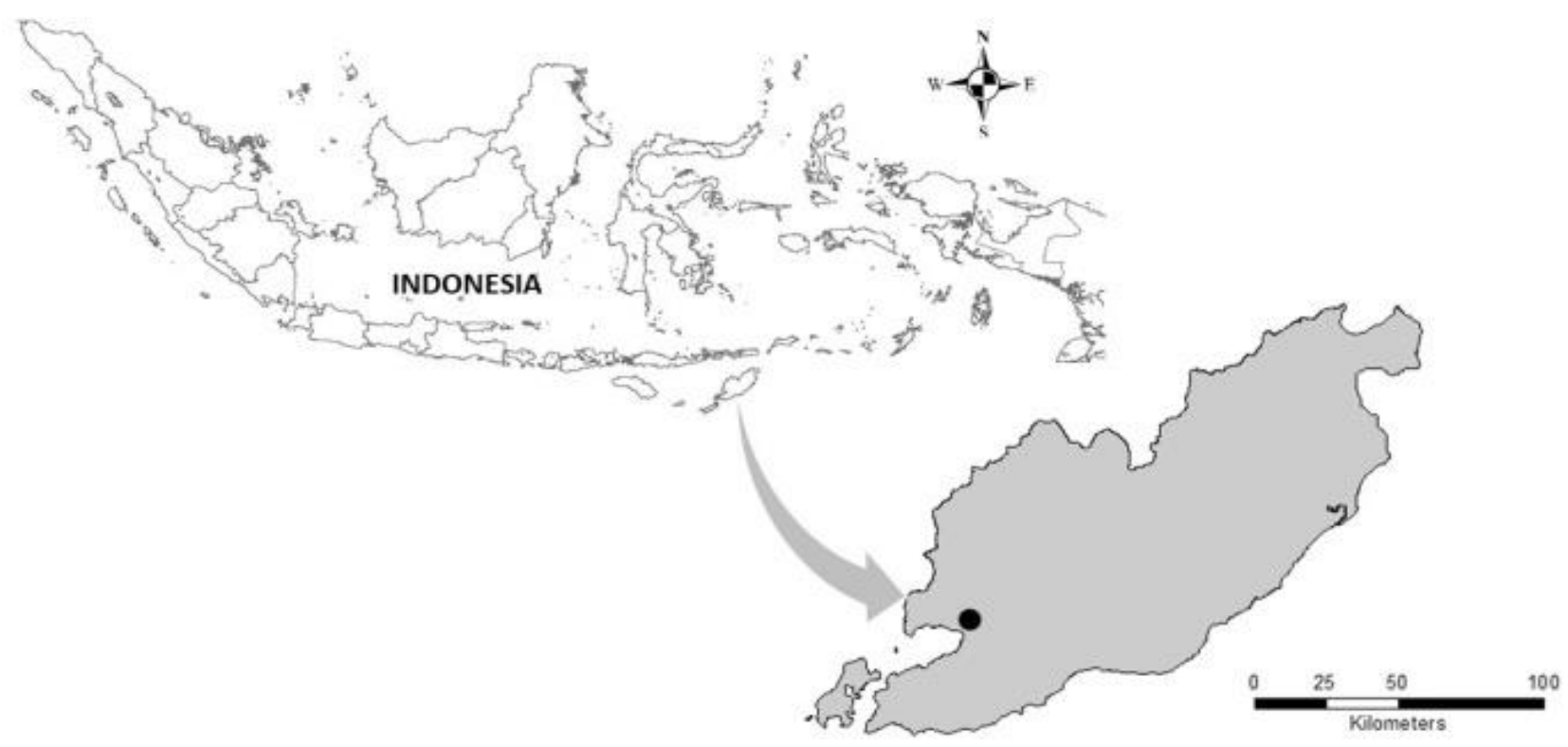

Figure 1. Location of Timor Friarbird study in the Bipolo Landscape of western Timor Island, Indonesia 
Bipolo Landscape is one of the distribution areas for Timor Friarbird on Timor Island. Primarily, the location consists of primary dryland forest cover, presented in an evergreen natural form all year round. These species are known to only grow in the conservation area of the Bipolo Natural Recreation Area, and the location is forecasted to be the main habitat for other varied wildlife. In addition, the surrounding zones also play a supporting role in this cause, as observed in the form of monsoon forest vegetation. Particularly, this is considered a secondary dryland forest group, with certain features, comprising Corypha utan, savanna and eucalyptus vegetation (Eucalyptus alba). Also, these growth forms are predominant in the highlands of mountains and hills, while the lowlands comprise coastal forest features, including mangroves, certain palms, and certain seasonal and annual dryland agricultural plants. Furthermore, shrubs spread in the lowlands to the highlands, while the habitat diversity observed in this landscape potentially provides the food resources required, alongside cover and shelter, as well as an environment suitable for wildlife reproduction. The area is important for Timor Friarbird conservation efforts in the future (Lesmana et al. 2000).

The study location is characterized by a topography dominated by flat surfaces (slopes $0-3 \%$ ) in the lowlands, while the highland presents as wavy (slopes 3-8\%), wavy (slopes $8-15 \%)$, hilly (15-30\% slope) and mountainous (slopes> 30\%). Furthermore, lowland areas reportedly possess a land cover for plantations and water bodies, alongside agricultural cultivation, dominated by seasonal crops including corn and beans,, irrigated and rainfed rice fields. Particularly, the plantation forest cover predominantly comprises certain types of teak (Tectona grandis), johar (Cassia seamea), mahogany (Swietenia macrophylla) stands. In addition, the land cover of water bodies includes areas surrounding the water bodies are located along the coast, including borderless rivers and springs, swamps, check dams, irrigation networks, fish and salt ponds. Particularly, the existing salt ponds are in the form of Enterprises owned by the state (BUMN) or microenterprises, maintained by the local communities. The upland areas, ranging from choppy grounds to mountainous land covers are realized as a form of secondary dryland forest. Moreover, soils obtained from this location are classified in the following order: entizol, inceptisol, alfisol, molisol, and vertisol, according to the taxonomic classification commonly identified on Timor Island (Soil Survey Staff, 1999). Specifically, the clay of bobonaro, with marginal soil fertility levels has also been spotted in close proximity to the catchment area, with water on the Timor Island-NTT (Widiyono 2008). The dry season occurs between June and September, while the rainy period extends from December-, with a rainfall level of $64 \mathrm{~mm} /$ year, $1,009.2 \mathrm{mb}$ air pressure, and an average daily temperature of $26.4^{\circ}-28.9^{\circ} \mathrm{C}$. (Statistics of Kupang District 2019).

\section{Procedures}

\section{Sampling design}

The observation design for Timor Friarbird was developed using the Biogeography Branch's Sampling
Design Tool for ArcGIS by the dimension of 4x3,75 km2 was observed, and grid size $(500 \times 250 \mathrm{~m})$. This software is commonly used to determine specific measurements, including length (Brownson et al. 2020; Nghikembua et al. 2020).

The research location covering was divided into 8 observation lines, spaced by a distance of $500 \mathrm{~m}$, with a $250 \mathrm{~m}$ separation between the points in the observation path (Ferenc et al. 2014). Furthermore, grids were formed as the area of land use-specific units during vegetation analysis and Timor Friarbird distribution assessment (Figure 2). The land use was interpreted using Google Earth 2020 satellite imagery, with a maximum livelihood technique estimated to produce eight types of land cover, according to the SNI 7645: 2010 (BSN, 2010) classification, including Primary and secondary dryland forest, covering an area of $187.2112 \mathrm{Ha}$, and 132.3624 Ha, respectively, alongside shrub regions (99.0274 Ha), open and cultivation area at $107.7271 \mathrm{Ha}$, and $10.5182 \mathrm{Ha}$. These further consist of the water body observed on the border of a river without embankments, tributaries, and around springs within a $200 \mathrm{~m}$ radius, open areas with few trees estimated to rarely cover an area of 17,8907 Ha. In addition, the location also comprised development areas (in the form of settlements, educational buildings and offices, roads, alongside electricity and telephone infrastructure networks) (89.5275 Ha), Timber plantation forest $(184.4283 \mathrm{Ha})$ and Bipolo landscape with total area of 1,228.6928 Ha (Figure 2). The water, land and impermeable surfaces are common cover types on earth (Gomez et al. 2016), which individually determine the habitat for various flora and fauna forms (Ghorbanian et al. 2020). Particularly, Google Earth Engine (GEE) is a large geo-data processing platform developed for planet-scale geospatial analysis (Gorelick et al. 2017). This technology has a combined asset of free satellite imagery, assumed to continuously monitor the Earth's surface through reasonable spatial and temporal resolution (Zurqani et al. 2018). Also, the tool provides fast and easy prototyping, analysis, and visualization of large geospatial data through parallel processing with a web-integrated development environment (Ghorbanian et al. 2020). This is the most common cloud-based platform used by various experts for large geospatial data analysis (Kumar and Mutanga 2018). Therefore, high-resolution imagery on the study area ( $\mathrm{Li}$ et al. 2020) was collected, and combined with results from ground check, using a Garmin 78S GPS. The livelihood maximum classification approach was further adopted to classify and create land use and cover maps for the selected time period (Mekasha et al. 2020; Kaya and Görgün 2020).

The number of sampling points was determined by purposive sampling, based on the land cover area and usage obtained from ArcGis analysis, in order to observe Timor Friarbird habitat and distribution. Furthermore, vegetation observations were conducted at each bird encounter point and in the respective land cover type through the assumptions of specific qualitative parameters, including physiognomically and canopy stratification concerning the amount of sunlight received (Indriyanto, 2012). 

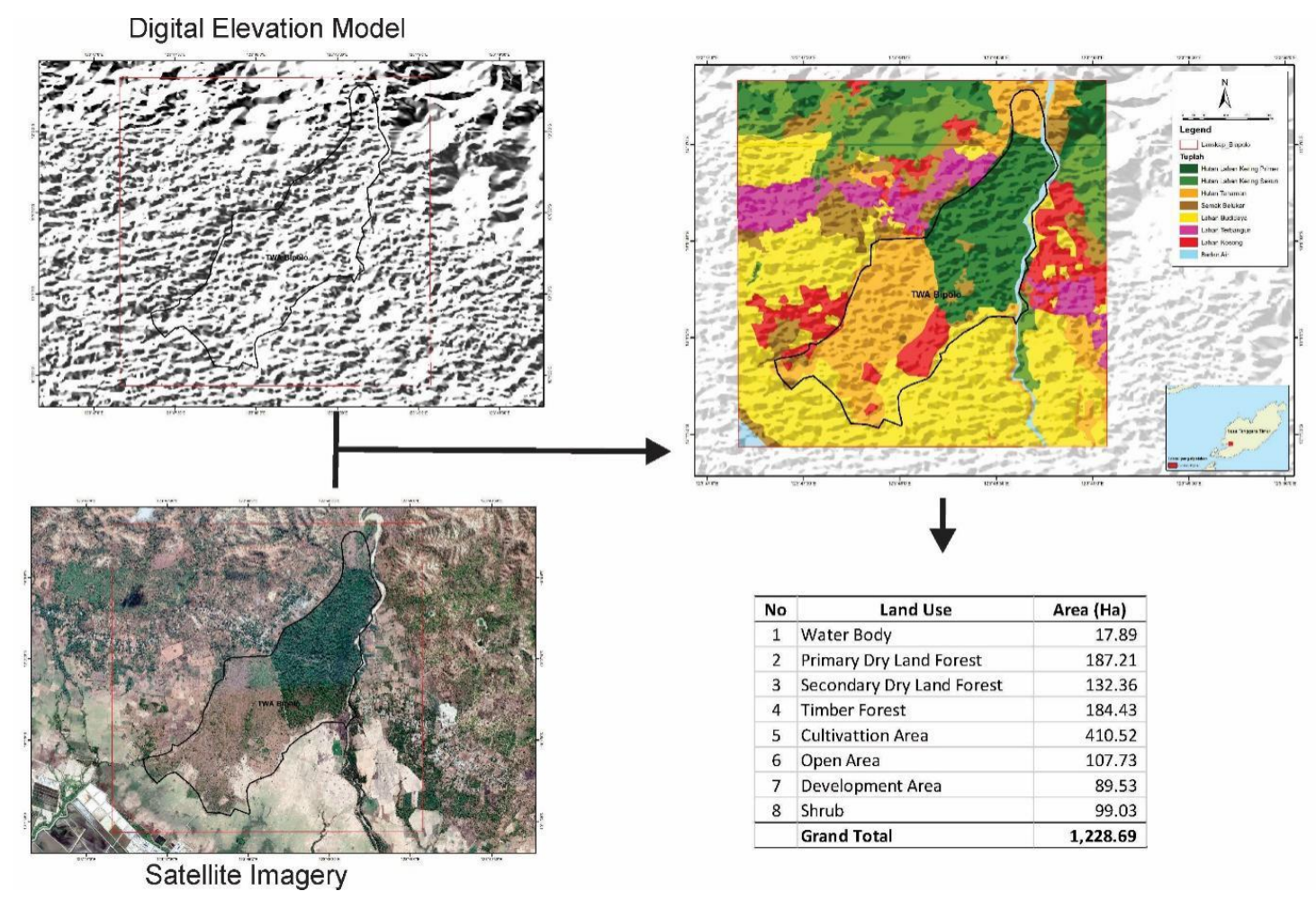

Figure 2. Process of land use interpretation

The vegetation canopy density level centered on the level of sunlight penetrating the forest floor or ground surface. Based on the theory above, three categories of vegetation canopy density were determined, namely, (i) high/very tight/closed, characterized by very dense physical appearance, implicated in the poor sunlight penetration through the entire forest floor/ground surface. (ii) medium category is less dense, and sunlight is able to penetrate part of the forest floor/ground surface through gaps present in parts of the vegetation canopy. (iii) low/ open canopy density is observed in areas with significantly open vegetation, with the potential to allow sunlight penetrate the entire forest floor/ground surface. The total number of sampling plots reportedly characterized by the absence and presence of Timor Friarbird amongst all eight cover types in the entire study area was calculated. Therefore, the structure and composition of the vegetation were evaluated as factors to assess the ecological characteristics, and include the following parameters; number of species, number of individuals, volume and density of vegetation constituents.

The bird distribution was observed inside and outside the line transect on each grid, which was previously determined using counting point and line transect methods (Bibby et al. 2000). Furthermore, the grid is also used for observational purposes, based on the capacity to serve as a guideline for boundaries, required to facilitate the identification of eight land covers, and also to analyze the vegetation in each habitat, alongside Timor Friarbird distribution.

\section{Vegetation sampling}

Nested sampling vegetation sampling was adopted in this research, where randomly located specimen were evaluated, according to the representation conditions of the eight land use cover types. The sampling units, including trees, poles, and saplings with plot sampling measured $20 \mathrm{x}$ $20 \mathrm{~m}^{2}, 10 \times 10 \mathrm{~m}^{2}$, and $5 \times 5 \mathrm{~m}^{2}$, respectively. In addition, the presence point was measured, assuming the vegetation characteristics are related to aves fauna (Strohbach et al. 2013; Ferenc et al. 2014; Beninde et al. 2015, Chang and Lee 2016, Campos-Silva and Peratelli 2020). Figure 3 shows the plots were spread across eight land cover types, and scattered in the entire study locations. Moreover, each land cover type was obtained from 1-3 measuring plots, depending on the similarity level between each and the constituents' vegetation density, under criteria specified in the sampling design. The data collected from each plot were based on the respective number, habitat type, land cover, species name and number, circumference at diameter breast height (dbh), and total vegetation height. Furthermore, the criteria for trees were $\mathrm{dbh}>30 \mathrm{~cm}$ and height $>3 \mathrm{~m}$, poles with $\mathrm{dbh} 15-<30 \mathrm{~cm}$, and a height $>3$ $\mathrm{m}$, and also sapling with $\mathrm{dbh}<15 \mathrm{~cm}$ and a height of 1.5$<3 \mathrm{~m}$. The volume was determined based on the measurement result of total standing tree height, using haga-meter, and diameter at a height of $130 \mathrm{~cm}$ from the base (diameter at breast height/dbh) to obtain the area of the base of the tree, poles and sapling. Subsequently, the number of individual species observed at each growth level was determined to obtain the vegetation density value on a plot. Therefore, the vegetation was sampled at each encounter point (Schmiegelow et al. 1997). The habitatspecific for grid and the affiliated coordinates were determined and recorded using Global Positioning System. 


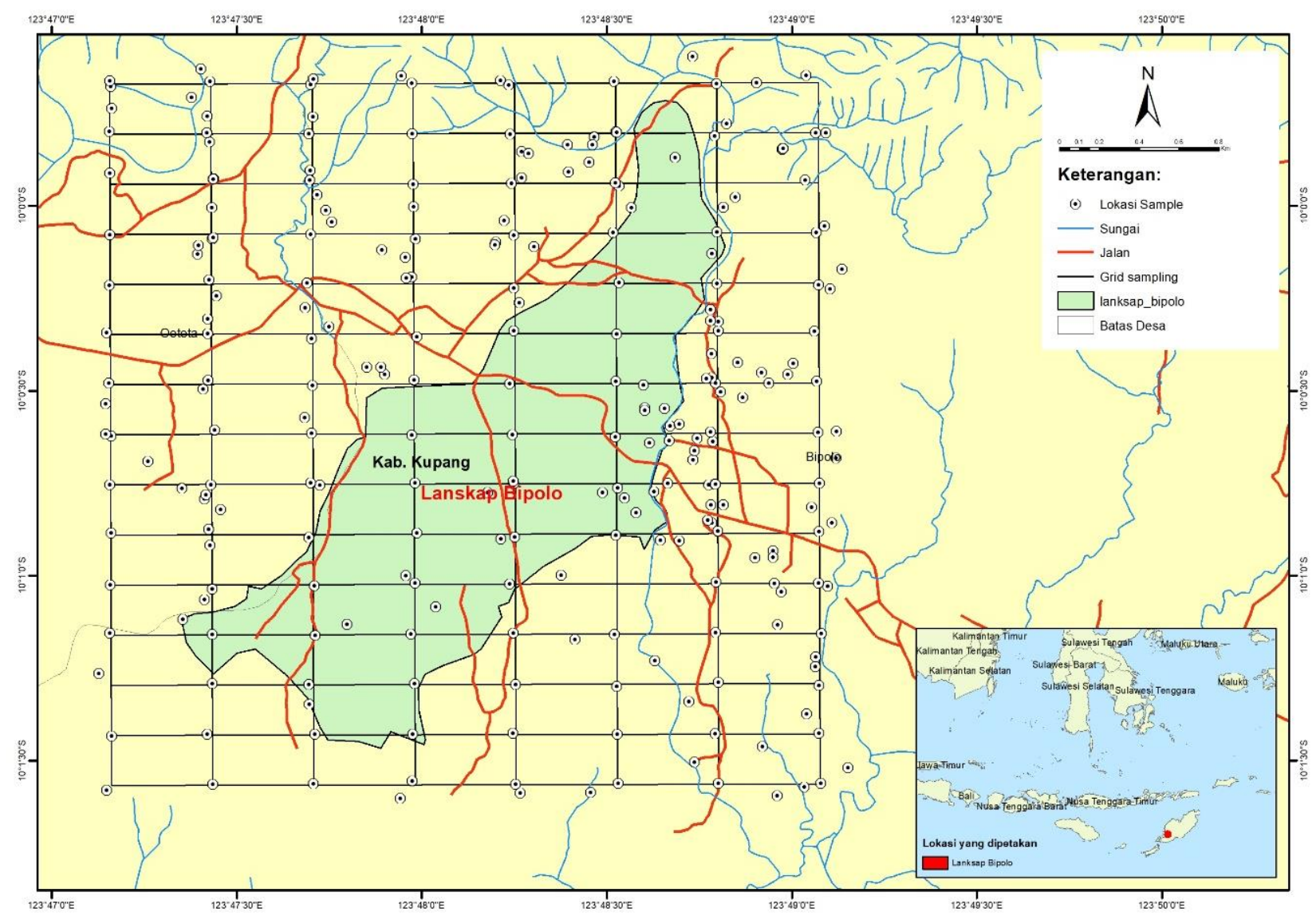

Figure 3. Sampling points location in Bipolo Landscape of Timor Island, Indonesia

The plant name was identified based on descriptive studies and the diagnostic characterization of parts images (Tjitrosoepomo 2003). The results were combined with direct species identification in the field by local guides, assumed to be experts in the name recognition of local specimens. Subsequently, the results were matched with a list of scientific names (BKSDA, 1996), while those with classification difficulties were labeled with temporary names, prior to further identification by competent parties (Isworo and Oetari 2020).

\section{Bird distribution}

The bird distribution data were collected using a combination of point count and line transect methods (Bibby et al. 2000), applied to observe the Timor Friarbird population. Furthermore, the distance of each observation transect line and between points on the line were determined to be $500 \mathrm{~m}$, and $250 \mathrm{~m}$, respectively, forming a grid of 12.5 ha. Therefore, each line transect had a length of $3.95 \mathrm{~km}$ and a total of 15 points with additional $100 \mathrm{~m}$ added to the outer boundary of the study area after the last at both ends. The first $50 \mathrm{~m}$ served as a bird-watching area, because observers are able to recognize clearly with the naked eyes in a single species observation, and without any magnifying device (Bibby et al. 2000). However, the next $50 \mathrm{~m}$ is considered the outer boundary of this research location.
The point count method is used to record bird encounters in the grid (outside the transect line). This is assessment is achieved when the observers walk to a specific area in all habitat or land cover within the grid, and marks the coordinates of the bird encountered with GPS (Machtans and Latour 2003), and records the number of individuals for 5-10 minutes before moving to the next point (Bibby et al. 2000; Campos-Silva and Piratelli 2020). Moreover, line transect method is used to estimate the birds recognized only within the transect line by continuously walking while observing, at a distance of $50 \mathrm{~m}$ on both sides (right and left) along the observation path. (Bibby et al. 2000; Machtans and Latour 2003).

Therefore, all data on the Timor Friarbird encountered from the two methods were recorded, including information on the number of individuals, location, weather conditions, altitude, bird activity/behavior, time, and duration of encounter (Bibby et al. 2000). The data distribution was consequently evaluated twice as much (Machtans and Latour 2003), in order to ascertain the presence in a prior location. These activities were conducted in November and December 2019, and within the time frame of 06.00-18.00. Furthermore, this practice was intended to ensure the proper observation of Timor Friarbird activities all day long, in attempt to elevate the total number encountered. Based on the presence and absence data obtained, Inverse 
Distance Weighted (IDW) and Kriging ArcGis were used to divide the bird zoning distribution.

\section{Data analysis}

Volume of tree

Standing stock estimation from Malamassam (2012);

$V i=$ bi.ti.f , and bi estimated through formula $b i=1 / 4 \pi d^{2}$

\section{Where:}

$\mathrm{V}$ : volume of tree ke-i $\left(\mathrm{m}^{3}\right)$

bi : basal area of individual no-i;

$\pi$ : phi $(3,14159)$;

$\mathrm{d} \quad$ : diameter $(\mathrm{m})$;

ti : height of tree no-i (m);

f : coefficient of stem : 0,7

\section{Density of vegetation}

Density (K) of vegetation estimated through formula by Indriyanto (2012).

\section{$\mathrm{K}=$ individual number of species/total sampling area}

\section{Analysis of bird distribution}

The Timor Friarbird distribution area was formulated based on the species primary data, through IDW interpolation and Kriging. Specifically, IDW is a deterministic spatial interpolation approach used to estimate the point value, using the closest known point, and not the farthest, while Kriging is a geostatistical method with the capacity to evaluate forecast quality, and predict error estimates (Chang 2019).

Furthermore, IDW analysis and ArcGIS Kriging were conducted to determine zoning of Timor Friarbird birds in three distribution areas, including the main, secondary, and low potential areas. Specifically, the main area is considered a primary zone for the specimen to obtain the best resources from both quality and quantity feed (flowers and insects) aspects as main food (nectar and insects), nesting, cover, shelter, and social activities. Second, the secondary zone is an area designated for Timor Friarbird expansion, and is required to ensure food resources, and is also a place known to mainly function as a location for refuge (resting during the day / taking shelter, sunbathing while searching), to avoid predators, and engage in social activities after searching for a meal in the morning and during the day. Third, low potential areas are characterized by limited resources, vegetation for nesting sites, cover, shelter, and social activities, resulting from poaching and disturbing habitat pressure. In addition, Biogeography Branch's Sampling Design was produced as part of an iterative sampling design development process, where existing data informs novel related decisions. Therefore, the objective of this process and the expected product includes an optimal sampling design with potentials for use to achieve accurate, high-precision estimates of population metrics (Landis et al. 2013).

\section{Discriminant analysis}

The determinants of Timor Friarbird's presence are limited by the assumption of several vegetation factors or parameters. Furthermore, the data type for this study is realized in the form of qualitative categories/groups (nonmetric), including the presence (Y1) and absence (Y2) data obtained from all eight land cover types, as distribution area of this species. This shows a functional application as a dependent variable/criterion, while the independent variables termed predictor (X) include data on the vegetation characteristics (with quantitative ratio data type), which is assumed to determine the presence and absence of Timor Friarbird. Moreover, a total of nine vegetation characteristic parameters were tested, including data on vegetation type (e.g., pile and sapling trees) and the total amount, respectively, as well as the land cover properties (trees, poles and sapling) quantified using a scoring system from one to eight. Based on this data type, discriminant linear regression analysis was used to distinguish the presence or absence at locations (plot) with specific vegetation characteristics. However, this test also determines the parameters estimated to have a significant influence, particularly in other locations. The discriminant analysis methods are usually applied to ornithological data (Buckton and Ormerod 1997; Buckton et al. 1998, Manel et al. 1999).

Discriminant linear regression analysis is a multivariate statistical technique designed to separate and allocate each unique object to a specific group (Johnson and Wichern 2007). This assessment technique is also used to classify individuals into independent groups, firmly based on the independent (Mattjik 2004), or a function of changevariable linear combination, estimated to result in the best separation method, and to provide relatively close values in each unit (Annas and Irwan 2015). Moreover, sequential discriminant analysis is used to differentiate between groups and ascertain the variance percentage in the dependent variable as explained by independent factors (Manel et al. 1999). The linear approach is a popular classification method built with several assumptions on the general population covariance matrix across all classes (Sifaou et al. 2020). These must be fulfilled as parametric multivariate technique, including; The smallest group size must exceed the number of independent variables, the variables must follow a multivariate normal distribution, the variance/covariance matrix of the variables must be homogeneous across groups, while the multicollinearity among variables must be excluded (Nikita and Nikitas 2020). In addition, a total of 538 plots were assessed in this research across eight land cover types, with Timor Friarbird absent in 474 , and present in 64 . The discriminant analysis is most useful during the observation classification in two or more populations (Heil and Schmidhalter 2014), with linear forms the most widely used algorithm for dimensional and reduction purposes (Sanodiya et al. 2020). The specimen distribution within this natural habitat was determined by identifying area of residence across several land cover types as an independent variable, alongside the number of vegetation at the growth rate of trees, poles, and sapling. This discriminant analysis is estimated to be an 
accurate statistical technique applied to predict the appropriateness of an object to a specific category, provided the data involved is guaranteed as accurate (Annas and Irwan 2015).

The data were collected in the form of a sampling plot from each unit. These include information on the presence of Timor Friarbirdspecies as the dependent var Data, obtained at each sampling unit, in the form of sampling plots variable $(\mathrm{Y})$, and nine ecological characteristics data as independent variable (X). Furthermore, a total of nine were estimated, including $\mathrm{X} 1=$ tree land use cover, $\mathrm{X} 2$ $=$ number of tree individual, $\mathrm{X} 3=$ number of tree species, $\mathrm{X} 4=$ pole land use cover, $\mathrm{X} 5=$ number of pole individual, $\mathrm{X} 6=$ number of pole species, $\mathrm{X} 7=$ sapling land use cover, $\mathrm{X} 8=$ number of sapling individual, and $\mathrm{X} 9=$ the number of sapling species. The presence and absence data were represented by the number 1 (One) and 0 (Zero), respectively. Particularly, variable $\mathrm{Y}$ consists of two groups, including Y1 and Y2 for absence and presence data represented by 0 (Zero) and 1 (One), accordingly. As a form of land cover, variable $\mathrm{X}$ consists of eight types, obtained from spatial analysis results, using the ArcGIS 10.3 software. Therefore, the land cover types were scored with a scale of $1-8$, while data on the total number of species and individual tree vegetation (trees), alongside poles and sapling, were computed from the measurement results of each plot. These data were subsequently analyzed through R. Stat, by using R-Studio version 1.31.0.7.3.

The discriminant analysis stages include (1) data division into two groups, including $80 \%$ attributed to discriminant functions formation, and $20 \%$ for validation tests, where Cohen's Kappa statistics was used to examine classification accuracy. (2) conduct a T-stat test: two samples assuming unequal variance, to evaluate differences across the respective averages. This approach was performed to ensure proper data representation in each group, for both the absence and presence criteria.

The null hypothesis (H0) is stated "equal to" (=), and the alternative hypothesis (Ha) is stated "not the same as", by using a two-tail test (Sugiyono 1997). The dissemination test was initiated with prior probabilities of group tests, in attempts to assess the possible presence and absence of data levels for normal distribution. Subsequently, a matrix relationship is built between the dependent variable (Y), and the nine independent (X) variables. Therefore, R-studio was used to analyze and obtain the coefficient results of linear discriminant, and was presented in a scatter plots graph. The discriminant function was then created by identifying the linear coefficients to build a Discriminant value equation (D) (Heil and Shcmidhalter 2014) as follows:

$$
\mathrm{Di}=\mathrm{a}+\mathrm{b}_{1} \mathrm{x}_{i l}+\mathrm{b}_{2} \mathrm{x}_{i 2}+\ldots \mathrm{b}_{i n} \mathrm{x}_{i n}
$$

Where:

Di : represents the discriminant value of the subject k-i; A : represents the intercept model

$b_{\text {in }}$ : represents the weights for the-n independent variable for subject $\mathrm{i}$
$\mathrm{X}_{\text {in }}$ : represents the value of the- $\mathrm{n}$ independent variable for subject-i.

Based on the discriminant function value, the results obtained indicate the existence of three differentiated distribution groups of Timor Friarbird, including the main area, secondary area, and low potential areas. Furthermore, the values were separated by size (with numbers close to 1 , considered large, while those close to 0 were considered small) (Supranto 2004). This study involved a total of three groups, including the main area characterized by large numbers (close to 1 ), followed by medium (at between 0 and 1) attributed as secondary area, and small values (close to 0$)$ classified as low potential areas.

Therefore, Press'S Q values were determined based on $\mathrm{P}<01$, in attempts to predict the vegetation characteristic factors of all nine parameters, by predicting the presence and absence of Timor Friarbird within this natural habitat. The determination and grouping of independent variables/predictors or parameters included in both probable instances play a significant role during evaluation. Meanwhile, Discriminant analysis tests for the existence of significant differences between categories/groups, based on the independent variables, provide the greatest contribution to the probability of observing differences (Supranto 2004; Santoso 2010). Subsequently, MANOVA test is applied because the dependent variable (criterion) is greater than one, and has a category scale (Supranto 2004) of Y1 and Y2 for absence and presence data, respectively. These parameters potentially determine the equation usability.

The final step is test for validation of the predicted equation resulting from the discriminant operation, performed. This involved the Cohen Kappa statistic, estimated to be a chance corrected classification measure (i.e., a standard measure of improvement over random placement), particularly on instances where the prior probability is estimated based on the group sample size. Moreover, Kappa zero indicated no increase over odds, whileKappa one showed perfect assignment. Hence, a significantly lower value in contrast with correct classification rate depicts correctness, and consequently produces a predictable group, with increased classification rate (McGarigal et al. 2000).

\section{RESULTS AND DISCUSSION}

\section{Distribution of Timor Friarbird}

The Timor Friarbird is widely distributed in Timor Island (Coates and Bishop 2000; Trainor et al. 2008), from the Eastern part of Timor Leste territory to the western part of this island in Indonesia, as is characteristics in the Bipolo Landscape. This feature is important for biodiversity conservation in this dry tropical area, due to the richness in key bird species (approximately 26 bird species), in small and fragmented forest areas (Lesmana et al. 2000). Timor Friarbird is part of the approximately 250 species endemic in the Wallacea region (Coates and Bishop 2000), and also consists of a fragment of the $386(26 \%)$ bird species endemic in Indonesia (Darajati et al. 2016). 
The results showed the dominant nature of Timor Friarbird species, due to the existence in every land type, with distinct encounter rates. In addition, the maximum encounter was approximately $43.75 \%$ in major timber plantation forests of Tectona grandis and gmelina (Gmelina arborea). However, moderate level was estimated at $15.63 \%$ in the primary dryland forests with high evergreen vegetation trees $>13 \mathrm{~m}$ of lightly open canopy and cultivation area, particularly for cashew farms, while the minimum was specified at $3.13 \%$ in water body and development area. Moreover, the species are possibly discovered in every land cover type (8). The Timor Friarbird was only present in 64 out of 538 total sampling plots (Figure 5). Habitat mismatch factors, selection behaviors, presence of other varieties (predators, competitors, and parasites) as well as various external physical-chemical environmental influences were limiting factors on the existence of the sample bird species (Krebs and Davies 1997).

The frequency distribution of Timor Friarbird is closely related to the structural characteristics and composition of the natural vegetation. Plant communities show a wide diversity contributing to the high supply (Asrianny et al. 2018) and therefore, individual species are generally used to assess the correlation between bird abundance (Cubley et al. 2020). Land cover exhibits an ecological relationship with avifauna species, due to high dependency on available foods (Tabba and Nurrani 2016).

Timor Island is dominated by monsoon forest and Monk et al. (2000), reported extensive vulnerability and easy-to-change attributes into savanna and grasslands, among other tropical forest formations. The abovementioned characteristics indicate an unstable plant community, due to various disturbances as potential limiting factors for wildlife survival, including Timor Friarbird. Meanwhile, stable plant conditions formed from several compositions and growth structures of seedlings, saplings, poles or trees, and free from various forms of habitat disturbance pressures showed signs of sustainability, availability, quality and quantity of food resources, nesting sites, covers, and shelters. Furthermore, social activities for wildlife, specifically Timor Friarbird, are needed to maintain high survival rates. The results of the discriminant function indicated the diversity of polelevel species with land cover (trees, poles, sapling) as the maximum contributing variable in determining Timor Friarbird existence, compared to other constraints. In addition, the association of these parameters tends to become a unitary function in this process, in an effort to maintain natural habitat stability. Nurrani et al. (2014) reported a possible uniform species distribution with a wide range of stable vegetation and the ability to meet the high demands of natural bird foods (Asrianny et al. 2018, Kamaluddin et al. 2019). However, unstable plant communities with unbalanced supply, tend to increase competition for limited resources (Kamaluddin et al. 2019). Furthermore, the availability of sustainable food sources influences the existence of birds settling for certain locations (Putri 2015).
Timor Friarbirds are classified as Family Meliphagidae, which are classified as pollinators of plant flowers (Paga 2012) and too serve as controllers for insects (MacKinnon et al. 2010) population, known to be potential pests for plants (Prawiradilaga 1990; Dewi et al. 2007). Also, Timor Friarbird is classified as species generalist, with a capacity to live in various habitats (Paga 2012), or occupy large environments (Bender et al. 2017). These generalist species are key organisms, widely distributed, and tend to interact commonly during pollination (Valido 2004). In addition, they a wide range of food resources and extensive cover, and easily adaptable to various environmental conditions (McComb 2007).

Timor Friarbirds feed on nectar $(62.96 \%)$ and insects $(25.93 \%)$ as the main food, obtained in flower crowns, dry and rotten bark, and also attached to leaves with dense vegetation. Also, these species are known to sometimes eat fruits (11.11\%) (Paga 2012). Mackinnon et al. (2010) stated these supplies as common foods mainly consumed by nectarine groups. Also, nectar served as a source of water, nutrients, and energy (Silva 2018), although, Timor Friarbird was described as an insectivorous species. However, Rumblat et al. (2016) assumed the varying method of obtaining insects were responsible for insectivorous' varying feed guilds. These alterations in feeding behavior of insectivorous birds were known to support the diverse bird feed guilds in the tropics (Blake and Loiselle 1991).

More than $95 \%$ of the plants discovered in the study area were flower producing food sources, including kapok forest (Bombax caiba/Gosampinus malacarica) gamal (Grilicidia sepium), turi (Sesbania grandiflora), Gmelina arborea, white gum (Eucalyptus alba), and black kabesak (Acacia catechu), dadap/nderas (Erithrina sp), lamtoro (Leucaena leucocephala), Jambu Hutan (Syzygium pycnanthum), taduk (Alstonia scholaris), Anacardium occidentale, mango (Mangifera sp), Tectona grandis, kesambi (Schleichera oleosa), Particular samples above were believed to be nesting sites, termed Anacardium occidentale, Alstonia scholaris and lamtoro (Leucaena leucocephala), as a place to sleep, shelter from predators and sunbathing and social activities (playing, singing) including, Schleichera oleosa, Cassia siamea, kedondong hutan (Spondias sp) (Paga 2012). In nature, Timor Friarbirds exist in pairs or groups, while performing foraging activities and others functions. The species in solitary, tend to move with high mobility conditions while foraging and high vocalization while perched at certain locations, and tend to migrate to a distant settlement in search of a group or partner.

Based on weekly species encounter data, a total of 53 samples showed an average encounter rate of 1-2 at each point. Occasionally, similar bird was observed at another plot point close to the previous position, due to varying land cover types, vegetation and canopy density levels. Paga (2012), reported a 1 bird per 2 ha estimated density of Timor Friarbird in western region of Timor Island. The value recorded for bird density was lower due to several factors, including severe habitat pressure from illegal logging and forest fires, land tenure conflicts, illegitimate 
grazing (inside and outside forest area), and significant unlawful poaching (Paga et al. 2015). Moreover, the report was supported by the community's opinion, where massive poaching with air guns and the reduction of food source trees, e.g. Bombax ceiba, Erithrina $s p$ occurred in the last two decades. These events instigated a decrease in the encounter rate of various bird species, particularly large body size $>20 \mathrm{~cm}$ as well as unique coat color and sound. The observation was in line with Lesmana et al. (2000), where anthropogenic disturbances included habitat destruction and three decades of massive poaching. Forest blocks on the western mainland of Timor Island extremely declined in biodiversity since the 1980s. Deforestation and native habitat conversion have significantly contributed to the massive loss of forest resources in recent decades (Garsetiasih et al. 2018). These anthropogenic disturbances demonstrated a great potential to transform habitat structures and resource availability and disrupt ecological interactions (Fontúrbel et al. 2017). Furthermore, Nurdin et al. (2017) assumed a declining bird population, due to a significant influence by human existence, compared to forest regions and vegetation density.

Nectivorous birds have the ability to select suitable distribution areas based on landscape type, species, and individual plant growth rates, especially for members of the Meliphagidae family, characterized by the ability to select nectar, based on preference for individual flowers containing nectar in abundant quantity (Scoble and Clarke 2006). The IDW analysis method and ArcGis kriging have determined the zoning distribution of Timor Friarbird birds, and a total of three zones were obtained. These include the main area (primary) of $473.8949 \mathrm{Ha}$, the secondary area (Secondary zone) of $693.029 \mathrm{Ha}$ and the low potential area of $940.2908 \mathrm{Ha}$, as shown in Figure 4. The daily distribution of Timor Friarbird was high during the period of foraging for nectar on the forest's edge, particularly in the primary zone. This phenomenon was principally observed in the morning before sunrise (5.30-8.30), and was followed by a search for nectar and insect in areas near the forest interior within the primary zone transitional area, and further approach the secondary area close to noon (8.30-10.00). The bird activities in the morning hours (10.00-15.00) include feeding on insects, resting, sheltering, perching, and sunbathing while searching, followed by sausage activities (playing in a group and singing) in the forest's interior (in cases of a forest area habitat) or regions with tightened canopy outside forested areas, for instance, cashew plantations in the secondary zone. Meanwhile, in the afternoon (3:00-6:00 p.m.) the birds' foraged in the forest's edge in the primary zone, slept in the transitional area between the primary and secondary zones, having dense or thick canopy on the vegetation of sapling, poles and trees around forested areas, river boundaries, mamar and cashew plantations. Mamar is a local wisdom system in a local agroforestry pattern, establish around springs, in the form of a combination of perennial productive plants with forestry plants, for instance, vegetation of areca nut (Areca catechu), banana (Musa sp.), Cassia siamea, Coconut (Cocos nucifera), pulai (Alstonia spectabilis), Swietenia macrophylla, Tectona grandis. Thus, Timor Friarbird is rarely in a low potential area (limited resource zone) due to significantly limited food resources (nectar, insects and fruits), cover, shelter, and social activities caused by anthropogenic pressure the habitat and illegal poaching.

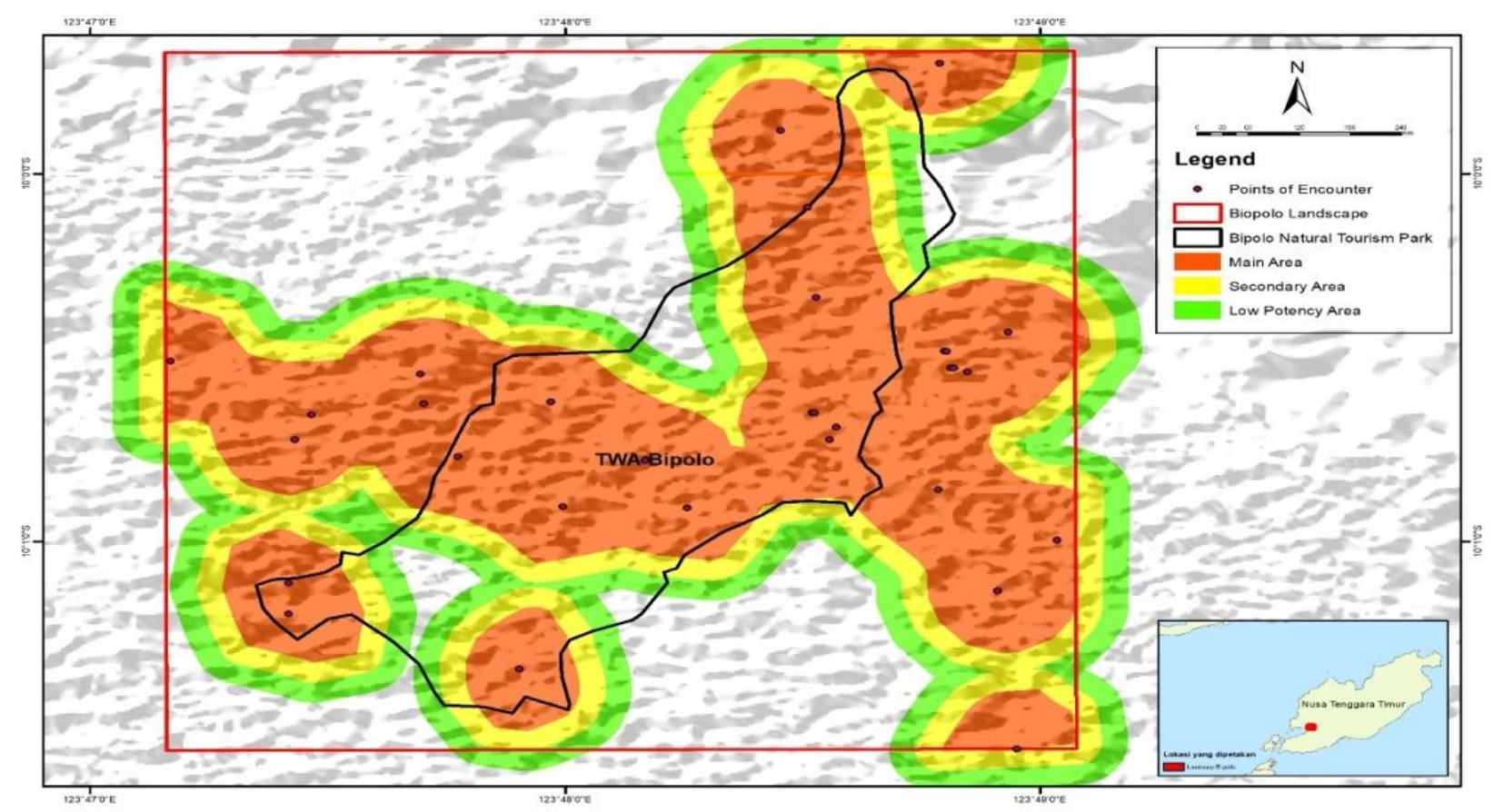

Figure 4. IDW Distribution map of Timor Friarbirdin Bipolo Landscape, Kupang, Indonesia 


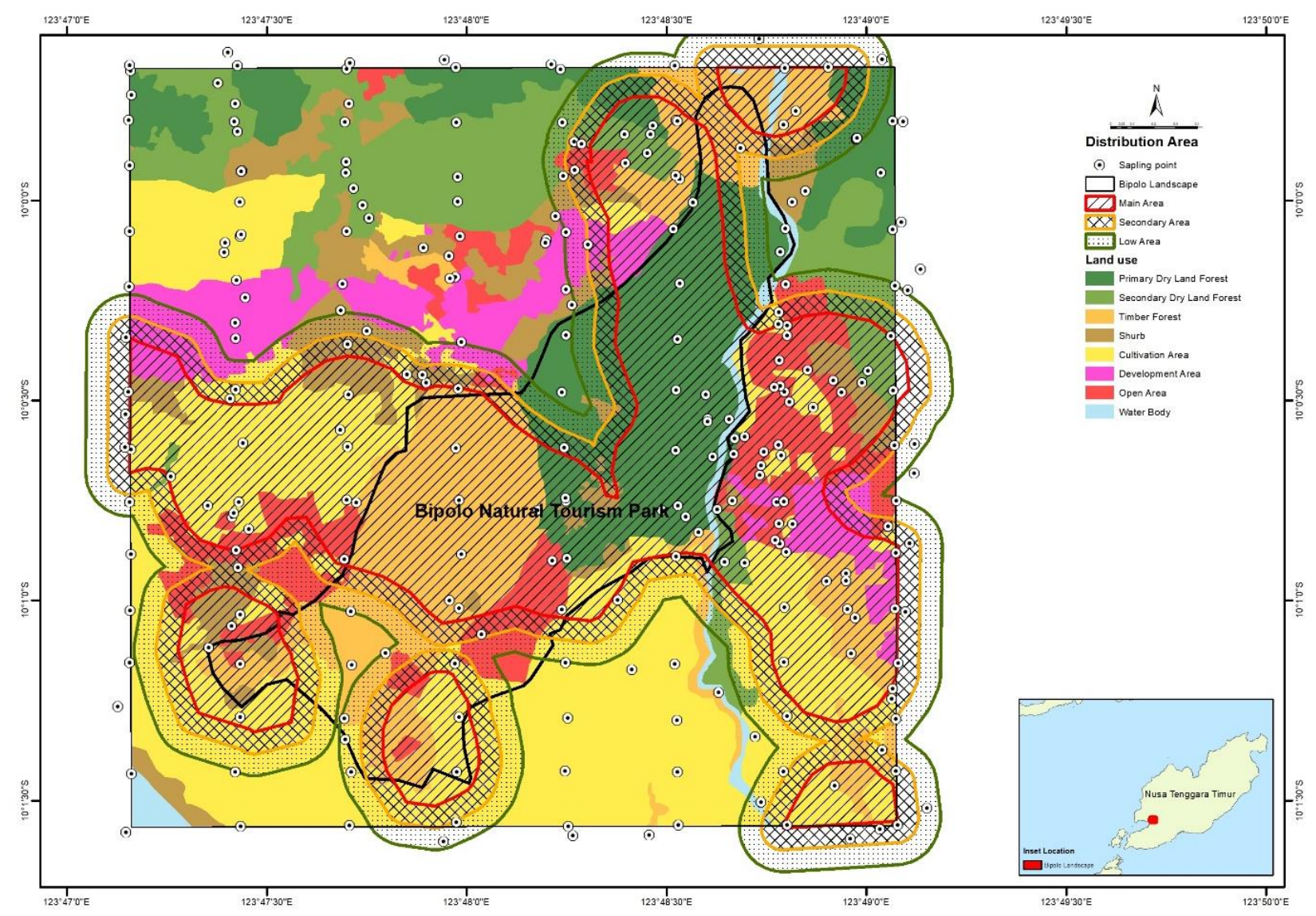

Figure 5. Map of Timor Friarbird distribution area overlayed to land-use type in Bipolo Landscape

Figure 5 shows the presence points found at an average distance of 241 meters from the present point to the border with the secondary area. The primary zone's vegetation characteristics are in the form of mixed evergreen vegetation in the forest's interior, commonly from the Malvaceae and Fabaceae families, as well as deciduous plants with a more open canopy, located on the Lamiaceae, Myrtaceae, and Anacardiaceae family forest edges, comprising growth strata of pole and tree vegetation above $12 \mathrm{~m}$ high, with some shrubs. The primary zone is more dominated by timber plantation forest land cover than other land cover types in the study area. Occasionally, Timor Friarbirds fly to forage for flowers in sapling-level, and rarely feed on seedling-level.

Food availability is also a major factor indicating the presence of birds (Herrera 1985; Novotny et al. 2006; Folmer et al. 2010; Plein et al. 2013), especially honeybirds (Putri 2015). In the primary zone, Timor Friarbird nectar food resources include Syzygium pycnanthum, Bombax ceiba, Cassia fistula L, Gmelina arborea, Sesbania grandiflora, and dadap/nderas (Erythrina sp.), fruit feed groups, for instance, fruit $S$. pycnanthum, an insect group commonly found in flowers and leafy groves, within the forest's interior. According to Schulze and Riedl, (2008), the presence of insects is higher in forest interiors, compared to edges. The fruit is commonly found on the forest's edge, and in community agricultural cultivation areas, for instance, palawija gardens, cashew plantations, and people's yards. The IDW analysis results and ground check in the field show the main areas for this species are forest areas with an evergreen interior, and a more open canopy at the forest border (Figure 5). Therefore, nectarivorous bird populations are denser in forest border areas (Schulze and Riedl 2008) and have habitat preferences of forest edges and interiors (Fontúrbel et al. 2021). A study by Brady and Noske (2009) showed that pen forests or forest edges with numerous shrubs and shrubs producing various kinds of plant flowers are a possible indicator of honeybirds' abundance within the area. In this condition, Timor Friarbirds obtain food resources (flowers and fruit as well as insects), and resting as well as nesting areas more easily. Mardiastuti et al. (2001) reported the tendency for fruit-eating birds to prefer upper canopy. This phenomenon is attributed to the ease of access and minimal competition from other species.

Timor Friarbird feeds on nectar and invertebrates with the potential for a different spatial-temporal distribution, within the environment. Furthermore, nectar is statically distributed, and resources are signaled visually and distributed disconnectedly, while invertebrate preys are cryptic, secret, mobile, and continue to be distributed to enable each prey item to be in any location, within a suitable microhabitat. The spatial-temporal distribution of different feed sources in the environment encourages 
nectar-eating birds and invertebrates to apply different selection pressures in cognitive mechanisms, in order to maximize time and forage efficiency (Sulikowski and Burke 2015). This condition is bound to encourage Timor Friarbirds' movement to the secondary area.

The secondary area is in a transition area from the primary zone, with a more open canopy to the forest's interior, having a tight and always green canopy in forested areas or plantation areas and mamar (Figure 5). The distance from the Timor Friarbird's presence point in the main area, to the secondary area's outer boundary, averages 345 meters, while the secondary area's radius is 104 meters. These birds use this zone as a shelter, for sunbathing while probing, avoiding predators and other sources of disturbance, as well as for social activities, including playing and singing in groups. The secondary zone's characteristic is a slightly dense to dense evergreen vegetation canopy in the forest's interior. However, sunlight is able to penetrate gaps in the zone's canopy, thus, enabling sunbathing activities while searching, dominated by vegetation of poles and tall trees above $12 \mathrm{~m}$. The relatively high tree height condition probably helps birds monitor the conditions of feed sources (nectar, insects, fruit) and disturbances from the surrounding environment more easily. Putri (2015) stated relatively tall trees and a fairly dense canopy are more preferred by honeybirds. The common vegetation types present within the secondary zone include Schleichera oleosa, Acacia leucophloea, banana (Musa sp), kedondong hutan (Spondias sp), as well as vegetation types in mixed forest habitats (mamar).

The areas with low potential are located at a distance of 553 meters from the point where Timor Friarbirds are present in the main area to the outer boundary, with a radius of 104 meters. Therefore, species identified outside these two zones potentially function as a buffer (green belt), particularly after adapting to the specified environment by utilizing resources for personal survival. This zone is generally located in areas directly adjacent to the center of human activity in each land cover type, and is estimated to potentially limit the convenience of Timor Friarbird's daily activities, during attempts to obtain the resources needed. Furthermore, some covers generally originate from forested areas recently converted to agricultural cultivation zones, as observed with gardens of various plant forms, including upland rice, maize, beans and others (palawija), rice fields. These include built-up areas, settlements, roads, electricity network infrastructure, school buildings, offices, and factories. Therefore, less potential zone features vegetation characteristics without the capacity to support Timor Friarbird, due to the very open nature. This outcome is also influenced by the presence of low pole growth levels, which are expected to serve as a source of food production, resting and playing. In addition, the absence of high and massive anthropogenic disturbance factor naturally instigates greater variation in land use and vegetation types, with reference to the number of individual species, which allows for higher levels of encounter.
The Timor Friarbirds were predominantly distributed (47 points) in Bipolo Natural Tourism Park, compared to the 17 points recorded in the surrounding areas. These conservation areas are characterized by more diverse vegetation, with evergreen growth property all year. In addition, the canopy provided comprises several layers, ranging from slightly open to dense, as well as a complete growth structure from seedlings to trees $>30 \mathrm{~m}$ high. This condition is potentially more stable to support the availability of feed resources, nesting and resting places (sleeping), alongside perching while sunbathing, exploring (preening), and other social activities. The forest areas with high wealth levels for food-producing plants, and the capacity to continuously produce leaves, flowers, seeds, and fruit all year is affiliated with more herbivorous birds (Putri 2015).

Timor Friarbird activities in this conservation area were recorded to be carrying out activities looking for nectar and insects, singing, resting (sleeping and perching) and socializing. The reproductive activities were not identified during this study, while nectar foraging was reported in areas outside the conservation area on nikis flowers (Cassia fistula), Mangifera sp, insects on kapok flower (Ceiba petandra), as well as rotten bark and stems in Tectona grandis. In addition, consumption of Anacardium occidentale pseudo fruit was also observed. The threat factors of poaching limit the specimens' presence, particularly in areas of concentration, where hunters prefer across both inner and outer areas. Meanwhile, hunters tend to carry air rifles daily, during trips to these gardens, rice fields, forests while grazing livestock, and performing other activities in this environment. This activity is performed to ensure self-protection while herding livestock in the forest, or hunting other wildlife besides birds. However, this is considered as a mere cover, as participants are more focused on the hunting process, particularly for consumable large bird species to secure a livelihood.

The distribution of Timor Friarbird is closely related to the availability of nectar and insect resources as the main food, alongside the presence of nesting sites, cover for shelter, and social activities in one place. These birds require locations guaranteed to provide all the basic needs, including food, water, space, shelter for cover, shelter for nest, and breeding location. Therefore, adequate food availability is expected to support breeding of organisms living under good habitat conditions (Adelina et al. 2016). Moreover, understanding the ecological characteristics of avifauna, encompassing the feed guilds related to ecological disturbances is an important indicator of ecosystem preservation. The response of bird species to habitat disturbance varies depending on the type of feed (Gray et al. 2007). Wong (1986) affiliated bird abundance in a certain area with the number of available feed sources. Beninde et al. (2015) reported on the significant importance of areas with vegetation structure characterized by local habitat, biotic and sound management variables in contrast with landscape, abiotic, or design. Hence, an expanse with these properties, measuring greater than 50 Ha is needed to prevent the extinction of species estimated as sensitive to rapid land cover changes. 


\section{Characteristics of vegetation}

Vegetation is an important part of the island ecosystem, which comprises different forms from each land. Therefore, it is necessary to collect some characteristic samples (Zhang et al. 2020), and measure the outcome from (eight) land cover type classes. The results from 273 plots show 35 categorized as primary dryland forest, 47 as secondary, 24 as shrubs, 21 in open areas, 70 plots I cultivation area, 10 as water body, 16 development areas, and 50 timber plantation forests. Furthermore, each land cover has a characteristic class dependent on the vegetation structure and composition (Table 1,2,3).

The structure and composition of trees in growing stage across all land cover types comprised an average of Corypha utan compared to others. Moreover, the water body areas are composed of 9 species predominated by Corypha utan (17 individuals out of 35 individuals). The primary dryland forest encompasses 25 tree species and was dominated by Eucalyptus alba (64 out of 263 total individuals). However, the secondary dryland forest encompasses 33 species with Corypha utan as the dominant type (144 of 338 total individuals). In addition, timber plantation forest composed of 25 species predominated by Tectona grandis in this land cover, at 204 of 400 total individuals, alongside 30 Corypha utan, which dominates the land cover at 101 of 212. The development area comprises 14 species and types of Mangifera sp, with significantly greater quantity in the land cover, at 15 of 58 individual tree plots. The open area consists of 10 Coryph utan species, known to be dominant the location at 61 of 94 total tree individuals, while shrubs compose of 19 species, and Corypha utan was estimated at 22 of 69. Table 1. shows the dominance of Corypha utan in the study area. This plant type is regarded as a wealth of biodiversity in the NTT savanna (Naiola et al. 2007), and is also considered a species with propensity to reduce the negative impacts of climate change, due to the intrinsic evergreen nature (Naiola and Nurhidayat 2009). In addition, they are also classified as solitary monocarpic plants with substantial resistance to water scarcity, and possess the capacity to occupy open areas as a constituent of seasonal forest communities or savanna ecosystems (Partomihardjo and Naiola 2009). The Corypha utan, Tectona grandis, and Mangifera sp. are known to have the largest number of individuals in each land cover, and are consequently the highest contributors to individual tree density per hectare. Moreover, the most significant value recorded was 81.53 ind./ha, as observed in Timber plantation forest land cover, while the lowest (31 ind./ha) was observed in shrubland cover. Table 1 shows the highest volume at tree level ( $81.63 \mathrm{~m} 3 / \mathrm{ha})$, with the lowest $(31.36 \mathrm{~m} 3 / \mathrm{ha})$ amongst shrubs. In addition, tree volume is assessed as a function of diameter (area of the base), where the height and trunk shape is evaluated. The samples with large width $(>45 \mathrm{~cm})$ and height $(>20 \mathrm{~m}$ ) were commonly recognized in the Bipolo Natural Recreation Area, especially in primary dryland forests, including the Bombax ceiba, nisum (Ficus sp.), and also in the timber plantation forest, where Tectona grandis was observed. These tree types are nectar and insect producers. Also, a high tree density value accompanied by dense crown indicates greater potential for the presence of insectivorous birds (insectivores). Therefore, conditions with denser individual trees and greater canopy cover tightness potentially reduce wind speed, and enhance the tendency to distinguish more insects (Desantoro et al. 2020). The value reported possibly increases insect species evenness and richness for insectivore birds (Taradipha et al. 2019).

Figure 6 shows the pole structure and composition during the growth stage in each land cover type is dominated by Tectona grandis compared to others. Table 2, showed the highest vegetation volume $\left(87.29 \mathrm{~m}^{3}\right)$ in areas with timber plantation, and the least $(11.00 \mathrm{~m} 3)$ in water bodies. Previous studies have shown the capacity for timber forest plantations to provide birds with potential habitat (Sweeney et al. 2010). These cultivation areas tend to have fewer species with lower densities compared to natural forests (Marsden et al. 2001; Lindenmayer et al. 2002; Barlow et al. 2002). In addition, generalist species including Timor Friarbird have been reported in plantation areas (Zurita et al. 2006; Paritsis and Aizen 2008). Also, water bodies, especially in the riparian areas, are important habitats for wildlife birds. This environment is created through the composition and restructure of near-stream vegetation, tied to hydrology, and is also sensitive to flow change (Cubley et al. 2020).

The structure and composition of the sapling's growing stage in each land cover type were most dominated by Gliricidia sepium, compared to the other types (Figure 7). Table 3 shows the vegetation volume for pole growth was highest $(0.91 \mathrm{~m} 3)$ in the primary dryland forest cover and lowest $(0.09 \mathrm{~m} 3)$ in the development area (Table 3$)$. According to Dendang and Handayani (2015), the species' dominating ability is due to high adaptability and tolerance to environmental conditions. The plantation and timber forests also provide potential habitats for birds (Sweeney et al. 2010).

Generally, the structure and composition of vegetation in the study area are plant species for producing Timor Friarbird bird feed. These specimens are a part of the 2,442 present in Nusa Tenggara (Darajati et al. 2016). Food availability also significantly affects the presence of herbivorous bird species (nectarivorous, insectivores and frugivores, granivores). These birds feed mainly on plant parts, including nectar and pollen (nectarivorous) (Ghadirian et al. 2008), plant fluids (Zobrist 2014), fruits (frugivores) (Corlett 2011; Plein et al. 2013), seeds, legumes (granivores) (Cueto et al. 2006), leaves, grasses, shoots (folivores) (Rodriguez-Ferraro et al. 2007). The diversity and abundance of forage trees (plant flowers) affects bird abundance in turn (McGrath et al. 2008; Sreekar et al. 2010). In addition, the availability of nectar varies seasonally, and is highest in June and October, but least from December to February, yearly (Brady 2009). 


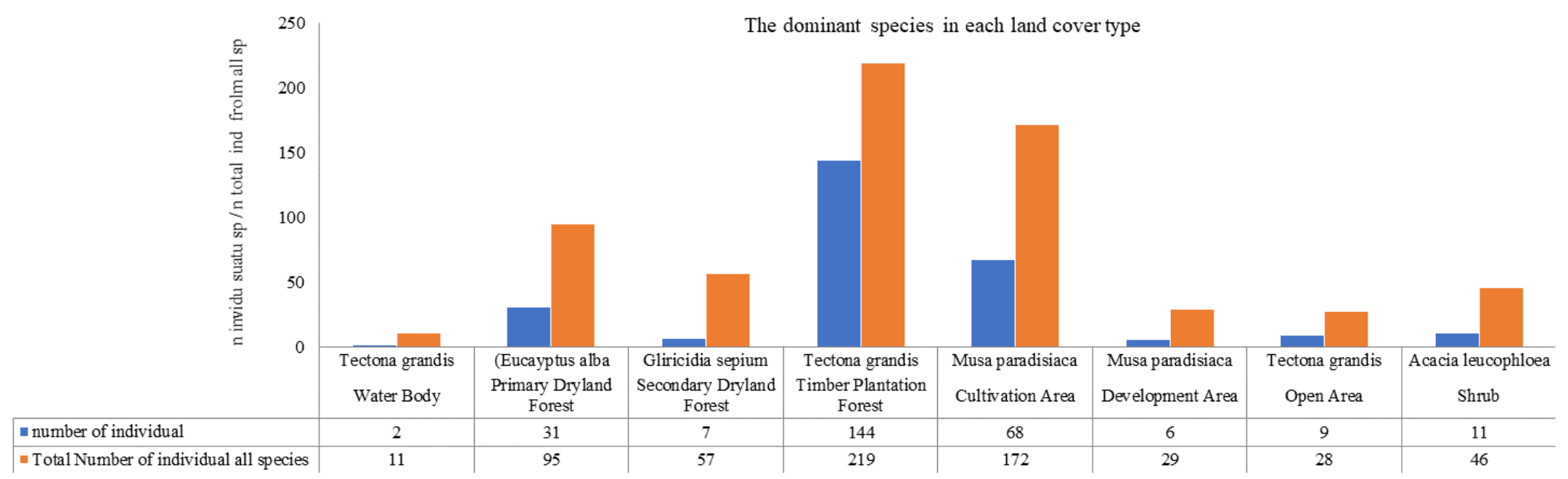

Figure 6. The dominant type of vegetation is pole level growth in each land cover type

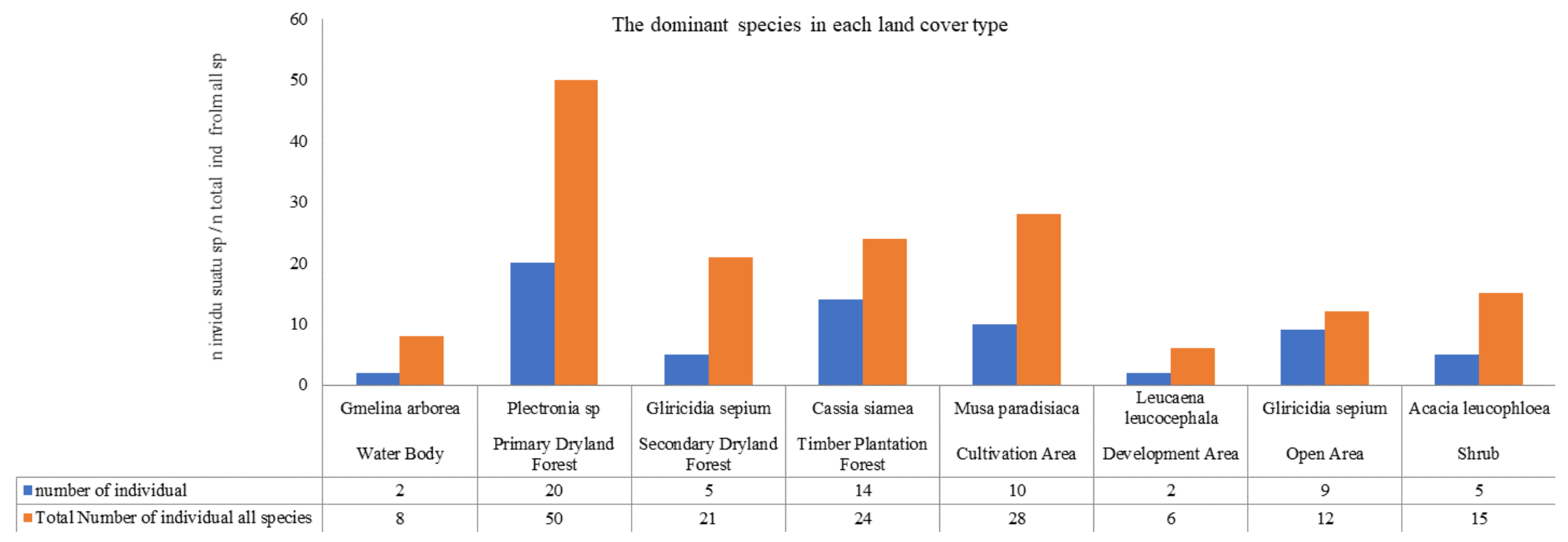

Figure 7. The dominant type of vegetation growth is the sapling rate in each land cover type 
Table 1. Structure and composition vegetation of tree

\begin{tabular}{lcccc}
\hline Land use & $\begin{array}{c}\text { Total number of } \\
\text { species (plot) }\end{array}$ & $\begin{array}{c}\text { Total number of } \\
\text { individual (plot) }\end{array}$ & $\begin{array}{c}\text { Total volume } \\
\left(\mathbf{m}^{\mathbf{3}}\right)\end{array}$ & $\begin{array}{c}\text { Density } \\
\text { (ind/Ha) }\end{array}$ \\
\hline Water body & 9 & 35 & 61.3874 & 35.00 \\
Primary dryland forest & 25 & 263 & 567.8471 & 55.96 \\
Secondary dryland forest & 33 & 338 & 890.2272 & 71.91 \\
Timber plantation forest & 25 & 400 & 653.8524 & 81.63 \\
Cultivation area & 30 & 212 & 470.4668 & 32.12 \\
Development area & 14 & 58 & 92.699 & 36.25 \\
Open area & 10 & 94 & 171.9729 & 44.76 \\
Shrub & 19 & 69 & 125.2567 & 31.36 \\
\hline
\end{tabular}

Table 2. Structure and composition vegetation of poles

\begin{tabular}{lcccc}
\hline Land use & Number of species & Number of individuals & Volume $\left(\mathbf{m}^{\mathbf{3}}\right)$ & Density \\
\hline Waterbody & 9 & 11 & 3.3657 & 11.00 \\
Primary dryland forest & 13 & 95 & 31.4948 & 20.21 \\
Secondary dryland forest & 25 & 57 & 28.344 & 12.13 \\
Timber plantation forest & 7 & 219 & 87.2947 & 44.69 \\
Cultivation area & 17 & 171 & 55.0398 & 25.91 \\
Development area & 9 & 29 & 8.1059 & 18.13 \\
Open area & 11 & 28 & 9.4596 & 13.33 \\
Shrub & 14 & 46 & 14.7654 & 20.91 \\
\hline
\end{tabular}

Table 3. Structure and composition vegetation of sapling

\begin{tabular}{lcccc}
\hline Land use & Number of species & Number of individuals & Volume $\left(\mathbf{m}^{\mathbf{3}}\right)$ & Density \\
\hline Waterbody & 6 & 8 & 0.1965 & 8.00 \\
Primary dryland forest & 9 & 50 & 0.9138 & 0.5358 \\
Secondary dryland forest & 13 & 21 & 0.4358 & 4.47 \\
Timber plantation forest & 8 & 24 & 0.8356 & 4.90 \\
Cultivation area & 8 & 28 & 0.0921 & 3.24 \\
Development area & 4 & 6 & 0.2368 & 5.71 \\
Open area & 4 & 12 & 0.4439 & 6.82 \\
Shrub & 5 & 15 & & \\
\hline
\end{tabular}

A study by Putri (2015) showed each forage-producing tree type has a different flowering and fruiting season, thus, the forage tree species' richness indicates continuity of feed availability throughout the year, while McGrath et al. (2008) reported arthropod abundance also influences bird abundance. The vegetation's structure and composition have influenced the taxonomic diversity and traits of avifauna, including birds', to further encourage higher diversity in green spaces, and increase ecological attributes. These characteristics enable the dependence of birds on the forest environment and resources, and further support sustained existence (Campos-Silva and Piratelli 2020).

\section{Determinant factor of Timor Friarbird distribution}

The discriminant analysis results for the nine vegetation characteristics' independent variables, on the Timor Friarbird presence and absence data, obtained the discriminant linear regression equation (D) below.

$\mathrm{D}=0.10109208 \mathrm{X} 1+0.07660775 \mathrm{X} 2+0.07446988 \mathrm{X} 3+$ $0.10109208 \mathrm{X} 4-0.89823159 \times 5+0.20152437 \mathrm{X} 6+$ $0.10109208 \times 7+0.01919516 \times 8-0.05933544 \times 9$
Based on the discriminant function coefficient's value, determining the presence or absence of Timor Friarbird in an area within the species' natural habitat is known from the total press'Q value, above 6.63501 and $p<01$. This total press'Q shows the minimum value of each vegetation characteristics' independent variables, with the ability to contribute to the Timor Friarbird's absence or presence. The MANOVA test results of the nine vegetation characteristics' independent variables thought to have an influence on the species' presence or absence had a significant effect on the species' presence in a location within the natural habitat, due to the critical value's distribution $(\mathrm{t}<\mathrm{t} 2)$. A smaller $\mathrm{t}$ value compared to the critical $t 2$ value, is bound to reduce this variable's contribution to the birds' presence or absence. Therefore, all these vegetation characteristic independent variables have a collective influence on the species' presence or absence at a location, in cases where the Press' $Q$ coefficient has a total cumulative value above $6.63501(\approx 7)$. In cases where each independent variable stands alone or is used separately, this discriminant function's is not suitable for determining this presence or absence within an area. 


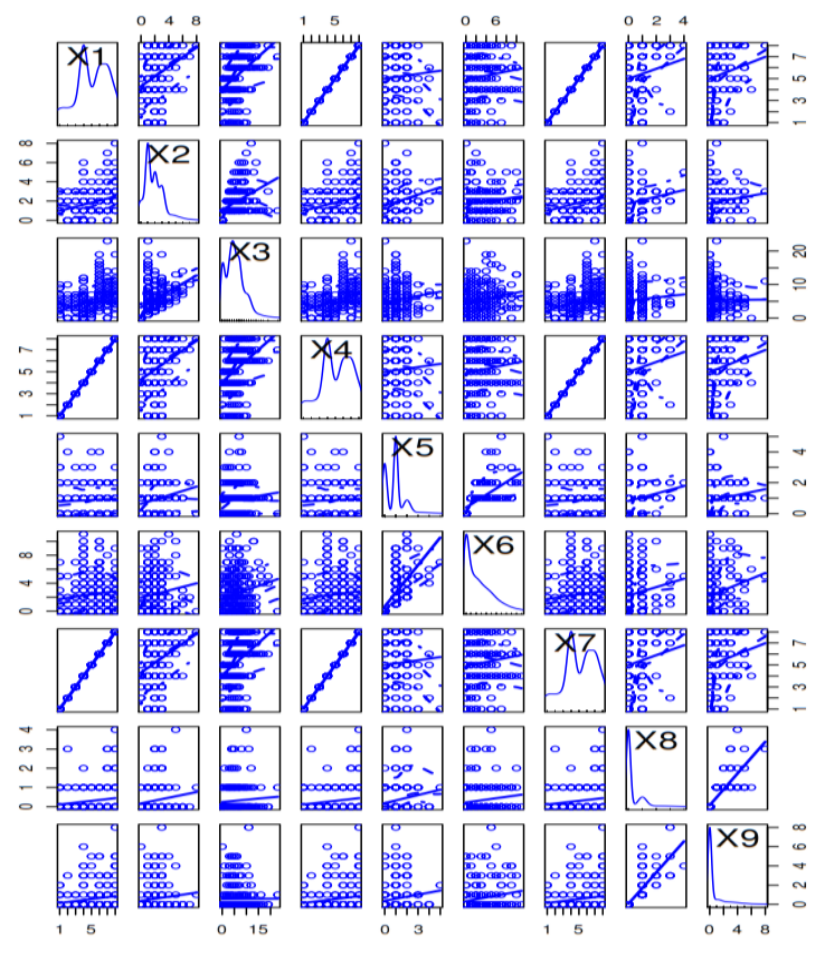

Figure 8. Scatter plot discriminant linear regression among dependent variables. Note: X1: tree land use cover, X2: number of tree individual, X3: number of tree species, X4: pole land use cover, X5: number of pole individual, X6: number of pole species, X7: sapling land use cover, X8: number of sapling individual, and $\mathrm{X} 9$ : number of sapling species.

Based on the discriminatory function coefficient (D)'s value for the Timor Friarbird's presence, this value is divisible into three functions of the resource utilization area for this bird species. These are the highest value group in the main area, with a value of 0.20152437 X6 (number of poles species), $0.10109208 \mathrm{X} 1$ (tree land use cover), $0.10109208 \mathrm{X} 4$ (pole land use cover ), 0.10109208X7 (sapling land use cover), the moderate value group in the secondary area, with a value of $0.07660775 \mathrm{X} 2$ (number of tree individual), $0.07446988 \mathrm{X} 3$ (number of tree species)and the lowest value group in the low potential area with a value of $0.01919516 \mathrm{X} 8$ (number of sapling individual), $0.05933544 \mathrm{X} 9$ (the number of sapling species), and 0,89823159 X5 (number of pole individual). Furthermore, there are two negative variables (number of pole individuals and the number of sapling species), meaning these variables do not contribute to the species' presence in a place. Meanwhile, the other seven variables have a positive discriminant coefficient, meaning these variables have a positive contribution to the species' presence in the habitat, naturally.

Vegetation characteristic variables with a discriminant coefficient value $\mathrm{D}$ above the others indicate the variables tend to be in the concentration point area for bird presence, with the potential to contribute the most to Timor Friarbird's presence in a location. The results above are clearly visible in the scatter plot (Figure 8), for instance, the variable number of pole species (X6) with the highest D value $(0.20152437)$ shows the diagonal line is more linear and the data distribution is more centered on the diagonal line of others. This shows the Timor Friarbird is more likely to be present in areas with a more diverse number of pole-level species in more open land cover areas, with shrubs associated with tree land cover (X1) poles land cover (X4), and sapling land cover (X7), with the height vegetation level of pole and tree above $12 \mathrm{~m}$. Areas with these vegetation characteristics function as main areas, generally located in forest edges, with a higher potential for providing food resources (nectar and insects), nesting sites, resting, and social activities. Paga (2012) stated the number of individuals (density) of tree-level vegetation forage associated with low pole-level vegetation density (more open canopy cover) is the most significant factor influencing the species' presence at a location within the natural habitat. The number of tree individuals (X2) associated with the number of tree-level vegetation species (X3) has the potential to become a secondary area. These vegetation characteristics are close to the primary dryland forest's interior, with a mixture of evergreen vegetation throughout the year. Meanwhile, the number of pole individuals (X5) with the least D value (-0.89823159) shows a non-linear diagonal line and a non-centered (scattered) data distribution. This variable is associated with the number of sapling individuals (X8) as well as sapling species (X9), and has a very low contribution to the Timor Friarbird's presence in a location. Generally, the characteristics of this vegetation are in low potential areas located far from the species' presence point, for instance, open areas (no vegetation at the level of poles and trees) in development areas, and water body areas.

According to previous research, Timor Friarbird is geographically spread on Timor island, from lowlands to highlands (Coates and Bishop 2000). The habitat characteristics are classified as generalist, thus, so the species are found in all habitats, accessing all feed resources (nectar and insects), nesting, resting and social activities (Trainor et al. 2008; Trainor 2002; Noske and Saleh 2000). However, the vegetation ecology variable with a certain value was never ascertained as a determinant factor. Thus, all vegetation variable characteristic in this study does not stand alone in determining the species' presence, and are therefore categorized as a new group, in cases where all are used in determining birds' presence within the natural habitat, with the discriminant function coefficient's limit value as in the discriminant equation (D) above. In addition, the Cohen Kappa model's accuracy shows a zero value, meaning there is no increase in proximity between the nine vegetation characteristics determinants, in cases where all the variables are used separately. Therefore, this model is recommended in determining vegetation characteristics with this newly formed group, and the Timor Friarbird's presence at a location within the natural habitat on Timor Island. 


\section{ACKNOWLEDGEMENTS}

The authors are grateful to the Home Affair Postgraduate Education Scholarships Program DIKTI for research funding, and also, to the Final Project Recognition (RTA) Program from Research Directorate of Universitas Gadjah Mada (UGM), Faculty of Forestry UGM, East Nusa Tenggara Provincial Government, Kupang District Government, Forest Planning Laboratory of Kupang State Agricultural Polytechnic, Center for Natural Resources Conservation (BBKSDA) East Nusa Tenggara for research implementation facilities, Arief Budiman who assisted in statistical data analysis and mapping, as well as everyone who have contributed to the success of this research.

\section{REFERENCES}

Adelina M, Harianto SO, Nurcahyani N. 2016. Keanekaragaman jenis burung di Hutan Rakyat Pekon Kelungu Kecamatan Kota Agung Kabupaten Tanggamus. Jurnal Sylva Lestari 4 (2): 51-60. DOI: 10.23960/js12451-60.

Annas S, Irwan. 2015. Penerapan analisis diskriminan dalam pengelompokan desa miskin di Kabupaten Wajo. Jurnal Sci Pinisi 1 (1): 34-43. DOI: $10.26858 /$ ijfs.v1i1.2117.

Arrijani, Setiadi D, Guhardjam E, Qayim I. 2006. Analisis vegetasi hulu DAS Cianjur Taman Nasional Gunung Gede-Pangrango. Biodiversitas 7 (2): 147-153. DOI: $10.13057 /$ biodiv/d070212. [Indonesian]

Asrianny, Saputra H, Achmad A. 2018. Identifikasi keanekaragaman dan sebaran jenis burung untuk pengembangan ekowisata birdwatching di Taman Nasional Bantimurung Bulusaraung. Jurnal Perennial 14 (1): 17-23. DOI: 10.24259/perennial.v14i1.4999. [Indonesian]

Bacchetta G, Farris E, Pontecorvo C. 2011. A new method to set conservation priorities in biodiversity hotspots. Plant Biosyst 146 (3): 638-648. DOI: 10.1080/11263504.2011.642417.

BKSDA [Balai Besar Konservasi Sumber Daya ALam VII] Kupang. 1996. Rencana Pengelolaan Taman Wisata Alam Camplong. Periode 1 April 1996 s/d 31 Maret 2021. Kabupaten Kupang Provinsi Nusa Tenggara Timur. Departemen Kehutanan Kantor Wilayah Propinsi NTT, Kupang. [Indonesian]

Barlow J, Mastre LAM, Gardnes TA, Peres CA. 2007. The Value of primary, secondary and plantation forests for Amazonian birds. Biol Conserv 136: 212-231. DOI: 10.1016/j.biocon.2006.11.021.

Bender IMA, Kissling WD, Böhning-Gaese K, Hensen I, Kühn I, Wiegand T, Dehling DM, Schleuning M. 2017. Functionally specialised birds respond flexibly to seasonal changes in fruit availability. J Anim Ecol 86 (4): 800-811. DOI: 10.1111/13652656.12683 .

Beninde J, Veith M, Hochkirch A. 2015. Biodiversity in cities needs space: a meta-analysis of factors determining intra-urban biodiversity variation. Ecol Lett 18 (6): 581-592. DOI: 10.1111/ele.12427.

Bibby C, Jones M, Masrsden S. 2000. Expedition Field Techniques Birds Surveys. Expedition Advisory Centre Royal Geographical Society. London.

BirdLife International. 2018. Philemon inonartus. The IUCN Red List of Threatened Species 2018: e.T2270476A13035188. DOI: 10.2305/IUCN.UK.2018-2.RLTS.T22704176A130351188.en.

Blake JG, Loiselle BA. 1991. Variation in resource abundance affects capture rates of birds in three lowland habitats in Costa Rica. Auk 108 (1): 114-130. DOI: 10.1093/auk/108.1.114.

BSN [Badan Standarisasi Nasional]. 2010. Klasifikasi Penutupan Lahan BSN Gedung Manggala Wanabakti, Jakarta, Indonesia. [Indonesian]

Brady CJ, Noske RA. 2009. Succession in bird and plant communities over a 24-year chronosequence of mine rehabilitation in the Australian monsoon tropic. Restor Ecol 18 (6): 855-864. DOI: 10.1111/j.1526-100X.2008.00511.x.

Brady CJ. 2009. Seasonality of nectar production by woodland plants on yyhe Gove Peninsula. North Territory Nat 21: 34-44.

Brownson K, Cox C, Padgett-Vasques. 2020. The impacts of agricultural windbreaks on avian communities and ecosystem service provisioning in the Bellbird Biological Corridor, Costa Rica. Agroecol Sustain Food Syst 45 (4): 1-39. DOI: 10.1080/21683565.2020.1838029.

Buckton ST, Ormerod SJ. 1997. Use of a new standardized habitat survey for assessing the habitat preferences and distribution of upland river birds. Bird Study 44 (3): 327-337. DOI: 10.1080/00063659709461068.

Buckton ST, Brewin PA, Lewis A, Stevens PA, Ormerod SJ. 1998. The distribution of dippers Cinclus cinclus (L.), in the acid-sensitive region of Wales, 1984-95. Freshw Biol 39 (2): 387-396. DOI: 10.1046/j.1365-2427.1998.00274.x.

Burung Indonesia. 2020. Infografis Status burung di Indonesia 2020. BirdLife International. https://www.burung.org/2020/02/17/ infografis-status-burung-di-indonesia-2020/ [Indonesian]

Campos-Silva LA, Piratelli AJ. 2020. Vegetation structure drivers taxonomic diversity and functional traits of birds in urban private native forest fragments. Urban Ecosyst. DOI: 10.1007/s11252-02001045-8.

Chang HY, Lee YF. 2016. Effects of area size, heterogeneity, isolation, and disturbances on urban park avifauna in a highly-populated tropical city. Urban Ecosyst 19 (1): 257-274. DOI: 10.1007/s11252015-0481-5.

Chang HT. 2019. Introduction to Geographic Information Systems. McGraw-Hill Education, New York.

Coates, BJ. Bishop KD. 2000. Panduan Burung-Burung di Kawasan Wallacea: Sulawesi Maluku, dan Nusa Tenggara. BirdLife International-Indonesia Programme \& Dove Publications Pty.Ltd., Bogor, Indonesia. [Indonesian]

Corlett RT. 2011. How to be a frugivore (in a changing worls). Acta Oecol 37 (6): 674-681. DOI: 10.1016/j.actao.2011.01.005.

Cubley ES, Bateman HL, Merritt DM, Cooper DJ. 2020. Using vegetation guilds to predict bird habitat characteristics in riparian areas. Wetlands 1-20. DOI: 10.1007/s13157-020-01372-8 .

Cubley ES, Bateman HL, Riddle SB, Holmquist-JohnsonC, Merritt DM. 2020. Predicting bird guilds using vegetation composition and structure on a wild and scenic river in Arizona. Wetlands 1-14. DOI: 10.1007/s13157-020-01371-9.

Cueto VR, Marone L, de Casenave JL. 2006. Seed preferences in sparrow species of the Monte Desert, Argentina: implications for seedgranivore interactions. The AUK 123 (2):358-367.

Dako, FX, Purwanti, RH, Farida, LRW, Sumardi. 2019. Kerusakan antropogenik kawasan hutan lindung Mutis Timau dan upaya penanggulangannya di Pulau Timor Bagian Barat. J Nat Recour Environmen Manag 9 (2): 437-455. DOI: 10.29244/jps1.9.2.437-455.

Darajati W, Pratiwi S, Herwinda E, Radiansyah AD, Nalang VS, Nooryanto B, Rahajoe JS, Ubaidillah R, Maryanto I, Kurniawan R, Prasetyo TA, Rahim A, Jefferson J, Hakim F. 2016. Indonesia Biodivertiy Strategy Action Plan (IBSAP) 2015-2020. Kementerian Perencanaan Pembangunan Nasional/BAPPENAS, Jakarta. [Indonesian]

Dendang G, Handayani WH. 2015. Structure and composition of forests stand in Gede Pangrango Mountain National Park, West Java. Pros Sem Nas Masy Biodiv Indon 1: 691-695. DOI: $10.13057 / \mathrm{psnmbi} / \mathrm{m} 010401$.

Desantoro TG, Hardina K, Hardikananda N, Pangestu FAS, Safitri S, Aziz A. 2020. Respon komunitas burung terhadap beberapa tipe habitat pada Ekosistem Artifisial di Wilayah PT PJB UP Paiton. JPSL 10 (3): 489-500. DOI: 10.29244/jps1.10.3.489- 500. [Indonesian]

Dewi RS, Mulyani Y, Santosa Y. 2007. Keanekaragaman jenis burung di beberapa tipe habitat Taman Nasional Gunung Ciremai. Media Konservasi 13 (3): 114-118. [Indonesian]

Dutta G, Devi A. 2013. Plant diversity, population structure, and regeneration status in disturbed tropical forests in Assam, Northeast India. J For Res 24 (4): 715-720. DOI: 10.1007/s11676-013-0409-y

Eaton JA, van-Balen B, Brickle, NW, Rheindt FE. 2016. Birds of The Indonesian Archipelago: Greater Sundas, and Wallacea. Lynx Editions Barcelona, Barcelona.

Ferenc M, Sedláček O, Fuchs R. 2014. How to improve urban green space for woodland birds: site and local-scale determinants of bird species richness. Urban Ecosyst 17 (2): 625-640. DOI: 10.1007/s11252-0130328-X

Folmer EO, Olff H, Piersma T. 2010. How well do food distributions predict spatial distributions of shorebirds with different degrees of self-organization? J Anim Ecol 79 (4): 747-756. DOI: 10.1111/j.1365-2656.2010.01680.x. 
Fontúrbel FE, Orellana JI, Rodrīguez-Gömez GB, Tabilo CA, Castań Valla GJ. 2021. Habitat disturbance can alter forest understory bird activity patterns: A regional-scale assessment with camera-traps. For Ecol Manag 479: 118618. DOI: 10.1016/j.foreco.2020.118618.

Fontúrbel FE, Salazar DA, Medel R. 2017. Increased resource availability prevents the disruption of key ecological interactions in disturbed habitats. Ecosphere 8 (4): e01768. DOI: $10.1002 /$ ecs2.1768.

Ghadirian T, Qashqaei AT, Dadras M. 2008. Notes on feeding and breeding habits of the Purple Sunbird Nectarinia asiatica (Cinnyris asiaticus) in Bandar Abbas, Hormozgan, Southern Iran. Podoces 2 (2): 122-126.

Ghorbanian A, Kakooei M, Amani M, Mahdavi S, Mohammadzadeh A, Hasanlou M. 2020. Improved land cover map of Iran using Sentinel imagery within Google Earth Engine and a novel automatic workflow for land cover classification using migrated training samples. ISPRS J Photogrammetry Rem Sens 167: 276-288. DOI: 10.1016/j.isprsjprs.2020.07.013.

Gomez C, White JC, Wulder MA. 2016. Optical remotely sensed time series data for land cover classification: A review. ISPRS J Photogrammetry Rem Sens 116: 55-72. DOI 10.1016/j.isprsjprs.2016.03.008.

Gorelick N, Hancher M, Dixon M, Ilyushchenko S, Thaou D, Moore R. 2017. Google Earth Engine: Planetary-scale geospatial analysis for everyone. Remote Sens Environ 202: 18-27. DOI: 10.1016/j.rse.2017.06.031.

Garsetiasih R, Rianti A, Takandjandji M. 2018. Potensi vegetasi dan daya dukung untuk habitat Gajah Sumatera (Elephas maximus sumatranus di areal perkebunan sawit dan hutan produksi KSI Kecamatan Sungai Menang, Kabupaten Ogan Komering Ilir. Berita Biologi 17 (1): 49 64. DOI: 10.14203/beritabiologi.v17i1.2997. [Indonesian]

Gray MA, Baldauf SL, Mayhew PJ, Hil JK. 2007. The response of avian feeding guilds to tropical forest disturbance. Conserv Biol 21 (1): 133-141. DOI: 10.1111/j.1523-1739.2006.00557.x.

Heil K, Schmidhalter U. 2014. Using discriminant analysis and logistic regression in mapping quaternary sediments. Math Geosci 46 (3) 361-376. DOI: 10.1007/s11004-013-9486-x.

Herrera CM. 1985. Habitat-Consumer Interactions in frugivorous birds In: Cody ML (ed) Habitat Selection in Birds. Academic Press, Orlando.

Indriyanto. 2012. Ekologi Hutan. Penerbit Bumi Aksara, Jakarta, Indonesia. [Indonesian]

Isworo S. Oetari, FS. 2020. Mangrove vegetation and bird communities around Tegal Port Central Java, Indonesia. Biodiversitas. 21 (4): 1551-1560. DOI: 10.13057/biodiv/d210436.

Johnson RA, Wichern DW. 2007. Applied multivariate statistical analysis. Edition $6^{\text {th }} \mathrm{ed} /$ Pearson Education Inc. Upper Saddle River, NJ. USA.

Kamaluddin A, Winarno GD, Dewi, BS. 2019. Keanekaraaman jenis avifauna di Pusat Latihan Gajah (PLG) Taman Nasional Waykambas. Jurnal Sylva Lestari 7 (1): 10-21. DOI: 10.23960/jsl1710-21. [Indonesian]

Kaya İ, Görgün EK. 2020. Land use and land cover change monitoring in Bandirma (Turkey) using remote sensing and geographic information system. Environ Monit Assess 192 (430): 1-18. DOI: 10.1007/s10661-020-08411-1.

Kumar L, Mutanga O. 2018. Google Earth Engine Application since inception: Usage, trends, and potential. Rem Sens 10 (10-1509): 1-15. DOI: $10.3390 /$ rs10101509.

Krebs JR, Davies NB. 1997. Behavioral Ecology; An Evolutionary Approach. Blackwell Publishing Company. Malden, MA., USA.

Landis MJ, Matzke NJ, Moore BR, Huelsenbeck JP. 2013, Bayesian analysis of biogeography when the number of areas is large. Syst Biol 62 (6): 789-804. DOI: 10.1093/sysbio/syt040.

Lesmana D, Trainor C, Gatur A. 2000. Arti penting hutan di daratan Timor Bagian Barat: Telaah awal informasi keanekaragaman hayati dan sosial ekonomi di Pulau Timor (Provinsi Nusa Tenggara Timur). BirdLife International-Indonesia Programme, Bogor \& Yayasan WWF Indonesia, Jakarta. [Indonesian]

Li W, Dong R, Fu G, Wang J, Yu L, Gong P. 2020. Integrating Google Earth imagery with Landsat data to improve $30-\mathrm{m}$ resolution land cover mapping. Rem Sens Environ 237 (111563): 1-16. DOI: 10.1016/j.rse.2019.111563.

Lindenmayer DB, Cunningham RB, Donnelly C, Nix H, Lindenmayer BD. 2002. Effects of forest fragmentation on bird assemblages in a novel landscape context. Ecol Monogr 72 (1): 1-18. DOI: 0.1890/0012-9615(2002)072[0001:EOFFOB]2.0.CO;2.
Machtans CS, Latour PB. 2003. Boreal forest songbird communities of the liard valley, Northwest territories Canada. Condor 105 (1): 27-44. DOI: 10.1093/condor/105.1.27.

MacKinnon J, Phillips K, van-Ballen B. 2010. Burung-Burung di Sumatera, Jawa, Bali dan Kalimantan (Termasuk Savah, Serawak dan Brunei Darussalam). Burung Indonesia, Bogor, Indonesia. [Indonesian]

Malamassam D. 2012. Membedah Potensi Hutan. IPB Press, Bogor, Indonesia. [Indonesian]

Manel S, Dias JM, Ormerod SJ. 1999. Comparing discriminant analysis, neural networks and logistic regression for predicting species distributions: A case study with a Himalayan river bird. Ecol Modeling 130 (2-3): 337-347. DOI: 10.1016/S0304-3800(99)001131.

Mattjik AA, Sumertjaya M, Wijayanto H, Indahwati AK, Sartono B. 2004. Modul Pelatihan Analisis Multivariat. Departemen Statistika, FMIPA IPB, Bogor, Indonesia. [Indonesian]

Marsden SJ, Whiffin M, Galetti M. 2001. Bird diversity and abundance in forest fragments and Eucalyptus plantations around an Atlantic forest reserve, Brazil. Biodivers Conserv 10 (5): 737-751. DOI: 10.1023/A:1016669118956.

Mardiastuti A, salim LOR, Mulyani YA. 2001. Perilaku makan Rangkong Sulawesi pada dua jenis ficus di Suaka Margasatwa Lambusango Buton. Media Konservasi 6 (1): 1-5. [Indonesian]

McComb BC. 2007. Habitat preference of coexisting species under selection and adaptive. Ecology 79 (2): 656-670. DOI: 10.1890/00129658(1998)079[0656:AMPOCS]2.0.CO;2.

McGarigal K, Cushman S, Stafford S. 2000. Multivariate Statistics for Wildlife and Ecology Research. Springer Verlag Inc., New York.

McGrath LJ, van Riper III, Fontaine J. 2008. Flower power: tree flowering phenology as a settlement cue for migrating birds. J Anim Ecol 1: 110. doi: 10.1111/j.1365-2656.2008.01464.x.

Mekasha ST, Suryabhagavan KV, Gebrehiwot M, 2020. Geo-spatial approach for land-use and land-cover change and deforestation mapping: A case study of Ankasha Guagusa, Northwestern, Ethiopia. Trop Ecol 61: 550-569. DOI: 10.1007/s42965-020-00113-6.

Monk KA, de Fretes Y, Reksodiharjo-Lelley G. 2000. Ekologi Nusa Tenggara dan Maluku. Prenhallindo, Jakarta. [Indonesian]

Naiola BP, Nurhidayat N. 2009. Biologi biji gewang (Corypha utan Lamack): Keragaman kandungan embrio, komia dan penanan mikroba dalam proses perkecambahan biji. Berita Biologi 9 (6): 773781. DOI: 10.14203/beritabiologi.v9i6.855. [Indonesian]

Naiola BP. 2007. Fisiologi biji dorman gewang (Corypha utan Lamarck). Berita Biologi 8 (5): 251-529. DOI: 10.14203/beritabiologi.v8i6.836. [Indonesian]

Newbold T, Scharlemann JPW, Butchart SHM, Sekercioglu ÇH, Alkemade R, Booth H, Purves DW. 2013. Ecological traits affect the response of tropical forest bird species to land-use intensity. Proc $\mathrm{R}$ Soc B: Biol Sci 280: 1750. DOI: 10.1098/rspb.2012.2131.

Nghikembua MT, Marker LL, Mehtätalo L, Appiah M, Pappinen A. 2020. Response of wildlife to bush thinning on the north-central freehold farmlands of Nambia. For Ecol Manag 473 (118330): 1-10. DOI: 10.1016/j.foreco.2020.118330.

Nikita E, Nikitas P. 2020. Sex estimation: a comparison of techniques based on binary logistic, probit and cumulative probit regression, linear and quadratic discriminant analysis, neural networks, and naïve Bayes classification using ordinal variables. Intl J Leg Med 134 (3): 1213-1225. DOI: 10.1007/s00414-019-02148-4.

Novotny V, Drozd P, Meller SE, Kulfan M, Janda M, Basset Y, Weiblen GD. 2006. Why are there so many species of herbivorous insects in tropical rainforests? Science 313 (5790): 1115-1118. DOI: 10.1126/science.1129237.

Nurdin, Nasihin I., Guntara AY. 2017. Pemanfaatan keanekaragaman jenis burung berkicau dan upaya konservasi pada kontes burung berkicau di Kabupaten Kuningan, Jawa Barat. Jurnal Wanaraksa 11 (1): 1-5. [Indonesian]

Nurrani L, Bismark M, Tabba S. 2014. Tipologi penggunaan lahan oleh masyarakat pada zona penyangga Taman Nasional Aketajawe Lolobata di Kabupaten Halmahera Timur. Jurnal Penelitian dan

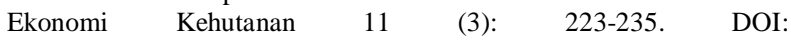
10.20886/jsek.2014.11.3.223-235. [Indonesian]

Noske RA, Saleh N. 2000. Ekologi Burung di Timor. Didalam: Kitchener DJ, Suyanto A. (eds.). Proceedings of the first international conference on eastern Indonesia-Australian vertebrate fauna. Manado, November 22-26. 1994 
Paga, B. 2012. Karakteristik Habitat Burung Cikukua Timor (Philemon inornatus) di Lanskap Camplong Kabupaten Kupang, Nusa Tenggara Timur. [Tesis]. Institut Pertanian Bogor, Bogor. [Indonesian]

Paga B, Mulyani, YA, Prasetyo LB. 2015. Karakteristik spasial habiat fisik burung cikukua timor (Philemon inornatus G.R.Dray, 1846) di Lanskap Camplong. Prosiding Seminar Nasional Biodiversitas Savana Nusa Tenggara. Balai Penelitian dan Pengembangan Lingkungan Hidup dan Kehutanan Kupang 14 November 2015. [Indonesian]

Paga B, Pudyatmoko S, Yuda IP, Faida LRW. 2020. Struktur dan komposisi vegetasi pada areal distribusi burung Philemon inornatus di lanskap Baumata, Kabupaten Kupang, Provinsi Nusa Tenggara Timur. Partner 25 (1): 955-968. DOI: 10.35726/jp.v25i1.439 [Indonesian]

Paritsis J, Aizen MA. 2008. Effects of exotic conifer plantations on the biodiversity on understory plants, epigeal beetles and birds in Nothofagus dombeyi forests. For Ecol Manag 255 (5-6): 1575-1583. DOI: 10.1016/j.foreco.2007.11.015

Partomihardjo T, Naiola BP. 2009. Ekologi dan persebaran gewang (Corypha utan Lamk.) di savanna Timor Nusa Tenggara Timur. Berita Biologi 9 (5): 637-647. DOI: 10.14203/beritabiologi.v9i5.2002 [Indonesian]

Plein M, Längsfeld L, Neuschulz EL, Schultheiß C, Ingmann L, Töpfer T, Böhning-Gaese K, Schleuning M. 2013. Constant properties of plantfrugivore networks despite fluctuations in fruit and bird communities in space and time. Ecology 94 (5): 1296-1306. DOI: 10.1890/12 1213.1

Prawiradilaga DM.1990. Potensi burung dalam pengendalian populasi serangga hama. Media Konservasi 3 (1): 1-7. [Indonesian]

Putri I. 2015. Pengaruh kekayaan jenis tumbuhan sumber pakan terhadap keanekaragaman burung herbivora di Taman Nasional Bantimurung Bulusaraung/Sulawesi Selatan. Pros Sem Nas Masy Biodiv Indon 1 (3): 607-614. DOI: 10.13057/psnmbi/m010338. [Indonesian]

Rachmat HH, Subiakto A, Wijaya K, Susilowati A. 2018. Alarming call from Mursala Island, North Sumatra: The urgent task of conserving the previously reported extinct of Dipterocarpus cinereus. Biodiversitas 19 (2): 399-405. DOI: 10.13057/biodiv/d190206.

Rodriguez-Ferraro A, Gracia-Amado MA, Bosque C. 2007. Diet, food preferences, and digestive efficiency of the grayish saltator, a partly folivorous passerine. The Condor 109:824-840.

Rumblat W, Mardiastuti A, Mulyani YA. Guild pakan komunitas buring di Jakarta. 2016. Media Konservasi 21 (1): 58-64. DOI: 10.29244/medkon.21.1.58-64. [Indonesian]

Sanodiya RK, Saha S, Matthew J. 2020. Semi-supervised orthogonal discriminant analysis with relative distance: integration with a MOO approach. Soft Comput 24 (3): 1599-1618. DOI: 10.1007/s00500 019-03990-9

Santoso S. 2010. Statistik Multivariat; Konsep dan Aplikasi dengan SPSS. Penerbit PT. Elex Media Komputindo, Jakarta, Indonesia. [Indonesian]

Schmiegelow FKA, Machtans CS, Hannon SJ. 1997. Are boreal birds resilient to forest fragmentation? An experimental study of short-term community responses. Ecology 78 (6): 1914-1932. DOI: 10.1890/0012-9658(1997)078[1914:ABBRTF]2.0.CO;2

Schulze C, Riedl I. 2008. Bird assemblages of forested and humanmodified countryside habitats in the Pacific lowlands of southern Costa Rica. Stapfia 88, zugleich Kataloge der oberösterreichischen Landesmuseen Neue Serie 80: 395-408.

Scoble J, ClarkeM F. 2006. Nectar availability and flower choice by eastern spinebills foraging on mountain correa. Anim Behav 72 (6): 1387-1394. DOI: 10.1016/j.anbehav.2006.03.024

Setiadi, D. 1984. Inventarisasi Vegetasi Tumbuhan Bawah dalam Hubungannya dengan Pendugaan Sifat Habitat Bonita Tanah di Daerah Hutan Jati, KPH Purwakarta, Jawa Barat, Bogor. Bagian Ekologi, Departemen Botani, Fakultas Pertanian IPB. Bogor. [Indonesian]

Sifaou H, Kammoun A, Alouni MS, 2020. High dimensional linear discriminant analysis classifier for spiked covariance model. J Machine Learn Res 21: 1-24.

Silva PA. 2018 Bird-flower interactions in an urban area: Ceiba pubiflora provides nectar and promotes biodiversity in the city. Urban Forestry and Urban Greening 36: 42-49. DOI: 10.1016/j.ufug.2018.10.003.

Sreekar R, Le PNT, Harrison RD. 2010. Vertebrate assemblage at a fruiting fig (Ficus caulocarpa) in Maliau Basin, Malaysia. J Conserv Sci 3 (2): 218-227.
Statistics of Kupang District. 2019. Kupang District in Figures 2019. Statistics of Kupang District, Oelamasi. [Indonesian]

Strohbach MW, Lerman SB, Warren PS. 2013. Are small greening areas enhancing bird diversity? Insights from community-driven greening projects in Boston. Landsc Urban Plann114: 68-79. DOI: 10.1016/j.landurbplan.2013.02.007.

Sugiyono. 1997. Statistika Untuk Penelitian. CV Alfabeta, Bandung, Indonesia. [Indonesian]

Sundarapandian SM, Swamy PS. 2000. Forest ecosystem structure and composition along an altitudinal gradient in Western South India. J Trop For Sci 12 (1): 104-123.

Sulikowski D, Burke D. 2015. Noisy miners plan ahead: cryptic signalling of reward location impairs search for nectar, but not for invertebrates. Anim Behav 102: 149-155. DOI: 10.1016/j.anbehav.2015.01.005.

Supranto. 2004. Analisis Multivariat Arti \& Interpretasi. Penerbit Rineka Cipta, Jakata, Indonesia. [Indonesian]

Supriatna J. 2018. Konservasi Biodiversitas: Teori dan Praktek di Indonesia. Yayasan Pustaka Obor Indonesia. [Indonesian]

Susilowati A, Elfiati D, Rachmat HH, Yulita KS, Hadi AN, Kusuma YS, Batu SAL. 2020. Vegetation structure and floristic composition of tree species in the habitat of Scaphium macropodum in Gunung Leuser National Park, Sumatera, Indonesia. Biodiversitas 21 (7): 3015-3033. DOI: 10.13057/biodiv/d210720.

Susilowati A, Rachmat HH, Elfiati D, Hasibuan MH. 2019. The composition and diversity of plant species in pasak bumi's (Eurycoma longifolia) habitat in Batang Lubu Sutam forest, North Sumatra, Indonesia. Biodiversitas 2 (20): 413-418. DOI: $10.13057 /$ biodiv/d200215

Soil Survey Staff. 1999. Kunci Taxonomi Tanah. Edisi Kedua. Pusat Penelitian Tanah dan Agroklimat, Badan Penelitian dan Pengembangan Pertanian, Departemen Pertanian, Jakarta. [Indonesian]

Somasundaram S. Vijayan, L. 2008. Foraging and guild structure of birds in the montane wet temperate forest of the Palni hills, South India. Podoces 3 (1/2):79-91.

Sweeney OFM, Wilson MW, Irwin S, Kelly TC, Halloran JO. 2010. Are bird density, species richness and community structure similar between native woodlands and non-native plantations in an area with a generalist bird fauna. Biodivers Conserv 19 (8): 2329-2342. DOI: 10.1007/s10531-010-9844-7.

Tabba S, Nurrani L. 2016. Avifauna pada Taman Nasional Aketajawe Lolobata berdasarkan tipologi zona dan tutupan lahan. Jurnal Wasian 3 (1): 25-38. DOI: 10.20886/jwas.v3i1.891.

Taradipha MRR, Rushayati SB, Haneda NF. 2019. Karakteristik lingkungan terhadap komunitas serangga. JPSL 9 (2): 394-404. DOI: 10.29244/jpsl.9.2.394-404. [Indonesian]

Tjitrosoepomo G. 2003. Morfologi Tumbuhan. Gadjah Mada University Press, Yogyakarta. [Indonesian]

Trainor, CR. 2002. A Preliminary List of Important Bird Areas in East Timor. BirdLife International Asia Division \& Vogelbesherming Nederland (BirdLife Netherlands), Bogor, Indonesia.

Trainor CR, Santana F, Pinto P, Xavier AF, Safftord R, Gremmett R. 2008. Birds, birding and conservation in Timor-Leste. BirdingAsia 9: $16-45$.

Valido A, Dupont YL, Olesen JM. 2004. Bird-flower interceptions in the Macaronesian Island. J Biogeogr 31: 1945-1953. DOI: 10.1111/j.1365-2699.2004.01116.x.

Widiyono W. 2008. Konservasi flora, tanah, dan sumberdaya air embungembung di Timor Barat Provinsi Nusa Tenggara Timur: studi kasus 'embung' Oemasi-Kupang dan 'embung' Leosama-Belu. J Tek Lingk 9 (2): 197-204. DOI: 10.29122/jtl.v9i2.462. [Indonesian]

Wong M. 1986. Trophic organization of understory birds in a Malaysian dipterocarp forest. Auk 103 (1): 100-106. DOI: 10.1093/auk/103.1.100.

Zhang L, Sun X, Su J, Liu X, Sun J. 2020. Discussion on sampling methods in island vegetation survey of species richness and biomass. IOP Conf Ser Earth Environ Sci 450: 012004. DOI: 10.1088/17551315/450/1/012004.

Zobrist KW. 2014. Recognizing Sapsucker Damage to Your Trees. Washington State University extension fact sheet Washington State University. Seattle, USA.

Zurita GA, Rey N, Varela DM, Villagra M, Bellocq MI. 2006. Conversion of the Atlantic Forest into native and exotic tree plantations: Effects on bird communities from the local and regional perspectives. For Ecol Manag 235 (1-3): 164-173. doi:10.1016/j.foreco.2006.08.009 
Zurqani HA, Post CJ, Mikhailova EA, Schlautman MA, Sharp JL. 2018. Geospatial analysis of land-use change in the Savannah River Basin using Google Earth Engine. Intl J Appl Earth Obs Geoinformation 69: 187-185. DOI: 10.1016/j.jag.2017.12.006. 